\title{
Review Article \\ Recent Development of Catalysts for Removal of Volatile Organic Compounds in Flue Gas by Combustion: A Review
}

\author{
Marco Tomatis, ${ }^{1}$ Hong-Hui Xu, ${ }^{2}$ Jun He, ${ }^{1}$ and Xiao-Dong $\mathrm{Zhang}^{3}$ \\ ${ }^{1}$ Department of Chemical and Environmental Engineering, University of Nottingham Ningbo China, \\ 199 Taikang East Road, Yinzhou District, Ningbo, Zhejiang 315100, China \\ ${ }^{2}$ Zhejiang Meteorological Science Institute, Hangzhou, Zhejiang 310008, China \\ ${ }^{3}$ School of Environment and Architecture, University of Shanghai For Science and Technology, Shanghai 200093, China
}

Correspondence should be addressed to Jun He; jun.he@nottingham.edu.cn

Received 6 November 2015; Accepted 28 February 2016

Academic Editor: Athanasios Katsoyiannis

Copyright (C) 2016 Marco Tomatis et al. This is an open access article distributed under the Creative Commons Attribution License, which permits unrestricted use, distribution, and reproduction in any medium, provided the original work is properly cited.

\begin{abstract}
Volatile organic compounds (VOCs) emitted from anthropogenic sources pose direct and indirect hazards to both atmospheric environment and human health due to their contribution to the formation of photochemical smog and potential toxicity including carcinogenicity. Therefore, to abate VOCs emission, the catalytic oxidation process has been extensively studied in laboratories and widely applied in various industries. This report is mainly focused on the benzene, toluene, ethylbenzene, and xylene (BTEX) with additional discussion about chlorinated VOCs. This review covers the recent developments in catalytic combustion of VOCs over noble metal catalysts, nonnoble metal catalysts, perovskite catalysts, spinel catalysts, and dual functional adsorbent-catalysts. In addition, the effects of supports, coke formation, and water effects have also been discussed. To develop efficient and cost-effective catalysts for VOCs removal, further research in catalytic oxidation might need to be carried out to strengthen the understanding of catalytic mechanisms involved.
\end{abstract}

\section{Background}

Volatile organic compounds (VOCs) refer to those organic chemicals that reach their boiling point at temperature lower than $250^{\circ} \mathrm{C}$ under the pressure of $101.3 \mathrm{kPa}$ [1]. The VOCs could be classified as non-methane hydrocarbons (NMHC) and oxygenated NMHC (including alcohols, aldehydes, and organic acids) [2]. The property and the risk involved with those pollutants vary according to their physicochemical characteristics. Common traits of the VOCs are their short lifetime in the atmosphere (from hours to months) and a small effect on radiative force [2]. The interest in those compounds is due to their contribution to the formation of photochemical smog and their hazardous effects on both atmospheric environment and human health [3-7].

Among the VOCs of anthropogenic origin, benzene, toluene, ethylbenzene, $\mathrm{m}, \mathrm{p}$, and o-xylenes (BTEX) represent a high percentage of the total emissions [8]. These compounds can be found during both indoor and outdoor atmospheric environment, which could be from various emission sources [8]. Most of the recent Chinese studies on air quality are focusing on this class of compounds due to their high concentration at ground level partially leading to the recurrent haze episodes [9]; in fact benzene is group I carcinogenic pollutant classified by International Agency for Research on Cancer (IARC) and ethylbenzene is a suspected group IIB carcinogenic compound, while both toluene and xylenes are IARC group III neurotoxins [10]. It is known that flue gases from various industrial processes are a major anthropogenic emission source of BTEX [11-13]. To remove these pollutants from flue gases different technologies have been developed and utilized. The thermal incineration is the most common process which uses high temperatures over $800^{\circ} \mathrm{C}$ to achieve the total combustion of highly concentrated VOCs [14]. Due to its high energy consumption this technology is expensive though the heat released from the incineration could be recovered; in addition, byproduct as $\mathrm{NO}_{x}$ and various reaction intermediates can be generated during 
the combustion [15]. An alternative to the thermal oxidation is the biological treatment, which uses microorganisms to treat small volume of low concentration VOCs containing exhaust. The biological treatment is selective and effective only for low weight and highly soluble hydrocarbons [16]. The physical or chemical adsorption of VOCs can be applied to a larger concentration range between 500 and 5,000 ppm, with efficiency usually superior to $95 \%$ [14]. The presence of water may affect the adsorption efficiency and it is also necessary to regenerate the adsorbent to remove the concentrated VOCs to extend its longevity for better cost-effectiveness. The absorption is a costly process where the pollutants are scavenged in a liquid for separation and recovery. It is useful to recover compounds that can have a market value and it is also critical to select a cost-effective solvent to ensure high removal efficiency [17]. Hence, the absorption technology does not degrade the pollutants but transfers them into another phase. The catalytic oxidation represents an alternative to the previously discussed processes by incinerating VOCs under much lower temperature and potentially accelerating the reaction rate [18]. The catalysts have been widely studied due to the potential economic advantage of this process.

The development of different types of catalysts for catalytic combustion of VOCs has been widely reported in the literature [19-22]. The review paper published in 2004 by Everaert and Baeyens presents a good overview of catalytic combustion of VOCs on theoretical combustion kinetics, performance of various classes of catalysts, and different reactor geometries [19]. Another review, focusing on catalytic combustion of VOCs on nonnoble metal catalysts, was published by $\mathrm{Li}$ et al. in 2009 [23]. A very recent review published by Aranzabal et al. in 2014 [24] was concentrated only on the catalytic oxidation of chlorinated volatile organic compounds, which discussed in detail catalyst selectivity, byproducts formation, the possible causes of deactivation, and so forth. This research area has been developing very quickly. Our review is to discuss the progress over the past decade comprehensively and specifically in the development of noble metal based catalysts, nonnoble metal oxide catalysts, perovskites, spinels, and dual functional adsorbentcatalysts. The effects of various supports, water, and coke formation would also be briefly reviewed. Though VOCs are a very broad group of organic pollutants concerning to atmospheric environment, our report is to concentrate on the typical VOCs including BTEX and some chlorinated VOCs in flue gas.

\section{Noble Metal Based Catalysts}

$\mathrm{Pd}, \mathrm{Pt}$, and Au are active phases commonly utilized in the catalytic oxidation process. These materials usually show the highest activity in removing BTEX, or more generally VOCs, from flue gases at low temperature.

2.1. Pt Based Catalysts. The Pt based catalyst shows high activity for the BTEX removal at temperatures between around $150^{\circ} \mathrm{C}$ and $350^{\circ} \mathrm{C}$ [25-28]. According to the literature
Pt should be the most active element for the oxidation of aromatic structures $[26,27]$, while, in the case of alkanes, it results in the most efficient catalyst only for molecular weight higher than pentane [26]. The reaction temperature necessary to achieve the required conversion percentage depends on the concentrations and properties of the chosen pollutants $[25,26]$. It has to be noticed that $\mathrm{Pt}$, as most considered active phases, does not directly interact with its support and keeps its physicochemical properties unchanged after it has been impregnated. The physicochemical characteristics of the supports could influence the deposition and particle dispersion of the active elements so as to affect catalysts' properties $[29,30]$ including their durability and resistance to poisoning.

$\mathrm{Wu}$ and Chang investigated the effect of supports with different degrees of hydrophobicity [25]. Their results showed that both activated carbon and styrene divinylbenzene copolymer (SDB) supports are able to preserve the catalyst activity well [25]. The hydrophobicity led to a toluene conversion efficiency $>90 \%$ for the SDB supported catalyst at $150^{\circ} \mathrm{C}$ while it was necessary to reach a range of temperatures between 180 and $200^{\circ} \mathrm{C}$ to achieve a complete conversion with the activated carbon supported catalysts [25]. A more recent work on the hydrophobic support was published by Joung et al. [30], in which a carbon nanotube (CNT) support was utilized $(30 \mathrm{wt} \% \mathrm{Pt} / \mathrm{CNT})$. The researchers were able to achieve a complete removal of a BTEX mixture (100 ppm each, space velocity $7.5 \times 10^{4} \mathrm{~h}^{-1}$ ) at $115^{\circ} \mathrm{C}$ against the $150^{\circ} \mathrm{C}$ previously required for the removal of toluene by using SDB support achieved by Wu and Chang [25]. It is worth mentioning that the weight load of Pt on the support in this study is 10 times the amount used by $\mathrm{Wu}$ and Chang ( $3 \mathrm{wt} \% \mathrm{Pt} / \mathrm{SDB}$ ). Even using the same impregnation method, different supports could achieve different particle dispersions $[25,27,29]$. It is understandable that better particle dispersion may allow a higher number of active sites with a consequent higher catalytic activity. The particle dispersion on the support is influenced by various factors including the presence of binding sites, surface area and morphology, and so forth. For example, the oxidation of an active carbon support, through acid treatment or air oxidation, generally leads to a better dispersion of the active phase since the metals tend to bind on oxidized sites [29]. Aksoylu et al. were able to demonstrate that the physical stability of the active carbon under the treatment could influence the active phase dispersion. In his study, it was noticed that the acid treatment $\left(5 \mathrm{~N} \mathrm{HNO}_{3}\right)$ in some cases led to a significant decrease of the micropore's volume due to the collapse of the pore structure [29]. The particle dispersion, calculated on the basis of the $\mathrm{H}_{2}$ adsorption data, revealed a dispersion value ranging from 0.13 for the nonoxidized samples to 0.92 for the acid treated samples that showed a higher physical stability [29]. It seems necessary to select the right supports in relation to the operating conditions, which would allow developing a suitable process able to achieve the required removal rate in the selected temperature interval.

During their studies on the internal mass transfer, Ordóñez et al. using Pt on a commercial $\gamma$-alumina (particle size $700-100 \mu \mathrm{m}$ ) demonstrated that the benzene conversion 
with original concentration of 2,000 ppm depends on the support's particle size only for diameter larger than $500 \mu \mathrm{m}$, while for particles of smaller diameter the internal mass transfer apparently did not show any limitation [26]. This result can probably be linked to the different tortuosity of the pore structure inside the particles of different size. A larger particle can show a more complex pore structure with a consequent reduction of the diffusion coefficient of the gas through the support.

Regarding the deposition of the active phase on the selected supports, various methods are available but the choice depends on the support type. Dry impregnation methods are often chosen to deposit this metal on porous support $[25,29]$ due to their higher deposition rate compared to the wet impregnation methods, while for deposition of metal on a zeolitic structure a different approach such as the cation exchange can be adopted [27].

2.2. Pd Based Catalysts. The Pd based catalyst operates at a slightly higher range of temperature between 200 and $300^{\circ} \mathrm{C}$ as compared to Pt [31-34]. The oxidation state of Pd influences its catalytic activity and Dégé et al. reported that $\mathrm{Pd}^{0}$ is the active phase and its catalytic performance is highly dependent on its load on supports [31,32]. To demonstrate this fact a zeolitic support, prepared with different $\mathrm{Si} / \mathrm{Al}$ ratios (4, 17 or 100$)$, loaded with Pd (0 to $0.8 \mathrm{wt} \%$ ) was reduced for $1 \mathrm{~h}$ under hydrogen at $300^{\circ} \mathrm{C}$. This treatment seemed to considerably increase its catalytic performances by achieving the xylene $\left(1,700 \mathrm{ppmv}\right.$, space velocity $\left.18,000 \mathrm{~h}^{-1}\right)$ complete oxidation around $240^{\circ} \mathrm{C}$ while it happened at $280^{\circ} \mathrm{C}$ for the same catalyst that was not reduced [32]. Other factors such as surface area, particle dispersion, metal load, and support characteristics also affected this catalyst's activity to some degree [32]. The tests result clearly showed that the number of accessible atoms of palladium is proportional to the catalyst activity [32], which is highly dependent on the metal load. Nevertheless, it has to be considered that particle size and dispersion will also heavily influence this parameter. If large palladium particles or aggregates are considered large numbers of palladium atoms, which act as active sites for the catalytic oxidation, not all of these atoms within such a block will be available for the reaction so as to lower catalytic efficiency of active phase. Formation of coke at low temperature was attributed to the acidity of the previously described zeolitic support. In fact from the results it appears that, for any condition tested (temperature, time on stream, or metal load), the conversion efficiency of o-xylene to $\mathrm{CO}_{2}$ was better for higher $\mathrm{Si} / \mathrm{Al}$ ratio and the coke oxidation could be promoted by the presence of acidic sites [32]. For all of the tested catalysts the researchers noticed that with the increase of metal load the percentage of formed coke decreased; in addition, under the same temperature conditions, the removal of coke seemed easier at higher metal load [32]. These results suggest that the oxidation of o-xylene into $\mathrm{CO}_{2}$ is kinetically favoured in presence of Pd. Therefore the coke formation should mostly be located in part of the support not within the active phase [32]. More tests would be necessary to demonstrate the kinetics of the coke formation and oxidation to support this hypothesis.
Regarding the catalyst stability, Liu et al. were able to demonstrate that Pd based catalyst was more stable than Pt based ones for toluene removal [35]. In fact the Pt based catalyst (2.68 wt\% Pt deposited on active carbon fibers) activity began decreasing after 20 minutes test at $200^{\circ} \mathrm{C}$ (space velocity $15,000 \mathrm{~h}^{-1}$ and oxygen content $10 \mathrm{vol} \%$ ), while the Pd based catalyst ( $0.42 \mathrm{wt} \%$ Pd deposited on active carbon fibers) remained stable for the whole 350 minutes of oxidation test in the same experimental conditions [35]. The Pd catalyst results have been reported to be more active for the oxidation of toluene than the Pt catalysts $[35,36]$ though it was said that Pt could be the most active phase for the oxidation of aromatic structures in other literature [26,27].

The same as for Pt based catalysts, cation exchange process was also recommended for the preparation of $\mathrm{Pd}$ based catalysts [31, 32, 37] as this methodology allows the introduction of the active phase inside the support structure instead of having a simple deposition on the support surface. Deposition-precipitation, wet or dry impregnation methods were also used to prepare this type of catalysts $[20,33,35,38]$.

It should be noted that the metal deposition, oxidation state of the active phase, and accurate quantitative analysis were rarely reported in the reviewed literature for all of the considered active phases.

Different supports were tested as it can be expected that differences in morphology and surface area can influence the catalytic activity [20,31,32]. Especially for the various forms of active carbon it can be noticed that physical and chemical properties of the support influence the metal deposition, dispersion, and the gas adsorption efficiency of the support $[20,35]$. It has been recently reported that active compounds such as titania $\left(\mathrm{TiO}_{2}\right)$ or Ni nanofibers doped with metals have been investigated $[33,34]$. These studies demonstrated that the activity of the Pd can be improved by modifying the support's characteristics with the doping of different metals $[33,34]$. Wahid and Tatarchuk reported that when PdO is doped with reducible metal oxides the catalytic activity depends on both the oxygen activation of Pd and the quantity of lattice oxygen on the reducible metal [33]. The use of metals such as $\mathrm{Mn}$ or $\mathrm{Ce}$, which show a great oxygen storage capacity, can positively influence the catalytic activity [33]. The results achieved by Barakat et al. using titania doped with $5 \mathrm{wt} \%$ Ce or $5 \mathrm{wt} \%$ Fe improved the catalyst activity and the presence of the dopants lowered the $\mathrm{T}_{50}$ by around $80^{\circ} \mathrm{C}$ (toluene $1,000 \mathrm{ppm}$, flow rate $100 \mathrm{~mL} / \mathrm{min}$ ) when compared to the basic titania [34]. During this study, it was found that the presence of Ce had the strongest influence on the catalytic activity [34]. Overall Pd based catalysts exhibit high activity for various classes of VOCs and they are more stable than Pt based catalysts, especially in presence of poisonous compounds such as chlorinated VOCs [39].

2.3. Au Based Catalysts. Au based catalyst tends to operate at higher temperatures compared to $\mathrm{Pd}$ and $\mathrm{Pt}$ ranging from 190 to $400^{\circ} \mathrm{C}$ for the removal of BTEX [40-43]. It is worth pointing out that the formation of coke was never reported as byproduct of incomplete combustion by using Au based catalyst for the oxidation of BTEX in the reviewed literature. This metal naturally exhibits a poor catalytic activity and 
it was considered almost chemically inert [40, 44]. The formation of metal-oxygen (M-O) bonds is rate determining for the oxides of $\mathrm{Au}$ while the breaking of $\mathrm{M}-\mathrm{O}$ bonds is the slow step for most other metal oxides [45]. This means that the largest part of the catalyst surface is in a metallic state without the possibility of exchanging oxygen, which could affect the oxidation efficiency negatively [41, 42]. It was reported that this metal's inertness could be overcome by developing composite oxides with $3 \mathrm{~d}$ transition metals which would enhance both catalytic activity and thermal stability [45]. In addition, it was also found that the catalytic activity of this noble metal is strongly influenced from its rate of dispersion on the support [40]. The use of gold nanoparticles supported on $\mathrm{Fe}_{2} \mathrm{O}_{3}$ managed to achieve the complete oxidation of toluene around $400^{\circ} \mathrm{C}(7,000 \mathrm{ppm}$ toluene and 10 vol\% oxygen, space velocity $\left.7.6 \times 10^{-3} \mathrm{~h}^{-1}\right)[40]$. Different methods have been applied to achieve the required particle dispersion including deposition-precipitation [34, $38,41,42,46]$ and coprecipitation [40, 42]. Particularly, the deposition-precipitation method proved to be able to produce gold particle of nanoscale between $<4$ and $8 \mathrm{~nm}$ [42, 46, 47].

In their interesting paper Zhang and Corma reported that the activity of the gold catalyst might not be correlated with the dimension of its dispersed particle, as long as the particle average diameter is nanometric, but with its oxidation state [48]. The experiment was conducted on different $\mathrm{Au} / \mathrm{ZrO}_{2}$ and $\mathrm{Au} / \mathrm{CeO}_{2}$ prepared with different ratio of $\mathrm{Au}^{3+} / \mathrm{Au}_{(\text {tot })}$; the temperature-programmed reduction (TPR) tests showed that even though it is not possible to completely deny the participation of $\mathrm{Au}^{0}$ and $\mathrm{Au}^{1+}$ in the catalytic process those two species are much less active than $\mathrm{Au}^{3+}$ [48]. However, this result does not agree with those in other previous studies which found that the catalytic activity of gold nanoparticle had high correlation with particle size, shape, and distribution $[42,43]$. More researches would have to be conducted for further investigation. In addition, metal reducibility seems to be one of the main factors to affect its activity while metal load might not be so critical [46] though higher metal load could increase accessibility to the gold particles on the catalyst's surface [41].

Recently a number of studies have been conducted focusing on how various supports would affect the Au based catalysts' capability, one of which was on three-dimensionally ordered (3DOM) $\mathrm{LaCoO}_{3}$ that was tested for the removal of $1,000 \mathrm{ppm}$ of toluene [43]. Compared to the bulk $\mathrm{LaCoO}_{3}$ this material showed a high quality $3 \mathrm{DOM}$ structure with more regular pore size and wall thickness and Au particles were better dispersed on the wall surfaces [43]. Catalytic tests conducted on these 3DOM catalysts showed independence of the VOCs oxidation efficiency from the space velocity [43]. The presence of oxygen species on the surface of such supports promotes the activation of atmospheric $\mathrm{O}_{2}$ on the vacant oxygen sites of these supports, which is favourable for the VOCs oxidation [43]. In addition, the gold doping promotes the mobility of lattice oxygen to improve its transfer to the vacancies and consequently increases the catalyst's activity [43].
Due to the high dispersion of small metal particles, the Brunauer-Emmett-Teller (BET) area of the support is usually only slightly reduced by the gold deposition [40, 41, 46]. Regarding the potential application of Au catalyst, it has to be reported that according to experimental observation by X-ray photoelectron spectroscopy (XPS), Fourier transform infrared spectroscopy (FTIR) and extended X-ray absorption fine structure (EXAFS) cationic gold cannot be stabilized on various materials as carbon and silica [48]. It was reported that the gold precursor tends to be reduced to its metallic state during the impregnation step due to the presence of $\mathrm{NaBH}_{4}$. Different deposition methodologies allow the presence of partially oxidized gold species $\left(\mathrm{Au}^{\delta+}\right)$, but this fact was observed only in case of low $\mathrm{T}$ thermal treatments (below $500^{\circ} \mathrm{C}$ ) [49] or in case of the modification of the support using different ligands [50]. These supports are commonly used for dual function catalysts, which could be a limiting factor in the use of gold in certain catalytic applications.

Though Au itself is almost chemically inert, it can increase the mobility of the lattice oxygen of the support's oxidized sites [40]. Minicò et al. using an $\mathrm{Au} / \mathrm{Fe}_{2} \mathrm{O}_{3}$ catalyst demonstrated, through TPR tests, that the presence of gold enhances the reducibility of the support, which favours the reduction of $\mathrm{Fe}_{2} \mathrm{O}_{3}$ to $\mathrm{Fe}_{3} \mathrm{O}_{4}$. The researcher found that the shift in the reduction temperature could not be correlated with change in surface area; hence, probably the presence of gold reduces the strength of the $\mathrm{M}-\mathrm{O}$ bond for $\mathrm{Fe}_{2} \mathrm{O}_{3}$, which could lead to the formation of more structural defects and consequent active sites [40]. A Mars-van Krevelen mechanism involving the lattice oxygen is able to justify the high activity of gold nanoparticles based catalysts [40]. Centeno et al. reported that $\mathrm{Au} / \mathrm{CeO}_{x} / \mathrm{Al}_{2} \mathrm{O}_{3}$ and $\mathrm{Au} / \mathrm{Al}_{2} \mathrm{O}_{3}$ show high activity for the removal of benzene ( $250 \mathrm{ppm})$ and its complete oxidation could be achieved at around $275^{\circ} \mathrm{C}$ with a space velocity of $9,700 \mathrm{~h}^{-1}$ [41]. An increase in the $\mathrm{Al} / \mathrm{Ce}$ ratio in gold containing catalysts was observed, which is probably due to the fact that $\mathrm{Ce}$ atoms mostly act as anchoring sites for $\mathrm{Au}$ nanoparticles [41]. Scirè et al. reported that the presence of $\mathrm{Au}$ enhances the activity of cerium oxide due to the presence of gold nanoparticles in the form of $\mathrm{Au}^{0}$, which could be formed by the calcination temperature higher than $300^{\circ} \mathrm{C}$ [42]. XPS tests found that the samples prepared by deposition-precipitation show a higher gold content on the support surfaces when compared to the coprecipitation method in accordance with other literature sources. The TPR profiles clearly show that the reduction peak of ceria is shifted to lower temperature with a consequent increase in its activity [42]. The catalysts were tested for the removal of toluene $(0.7 \mathrm{vol} \%)$ and the complete oxidation was reached at around $350^{\circ} \mathrm{C}$ for the catalysts prepared by DP but over $500^{\circ} \mathrm{C}$ as reaction temperature was needed to achieve the same efficiency for those catalysts prepared by CP [42]. According to the evaluation conducted on this type of catalyst's activity, the best $\mathrm{Au} / \mathrm{CeO}_{x} / \mathrm{Al}_{2} \mathrm{O}_{3}$ catalyst was the one prepared by Gluhoi et al. with smaller particle size and better dispersion [46].

However, high cost and sensitivity to the presence of poisonous compounds limit the industrial application of this 
type of Au contained catalysts; particularly, the presence of chlorinated compounds greatly affects the catalysts performances $[27,51,52]$.

2.4. Ag Based Catalyst. The use of Ag based catalyst for the removal of VOCs is also well documented for a large variety of experimental conditions. Most of these tests will not be described, since the scope of this review paper is to produce an in-depth overview on the progress of the catalytic oxidation process.

Baek et al. reported that an increase of the quantity of metallic $\mathrm{Ag}$ and $\mathrm{Ag}_{2} \mathrm{O}$ is detected, during X-ray diffraction (XRD) analysis, with the increase of the loading of $\mathrm{Ag}$ on HY zeolite [53]. During their tests, the researcher observed an increase of the catalytic activity to be correlated with the increase of the metal loading [53]. This result suggested that metallic Ag might be the active phase for toluene oxidation [53]. The transmission electron microscope (TEM) studies also showed an increase of the number of Ag nanoparticles with the loading; this factor might again be correlated with the increase of catalytic activity [53]. The results of the XRD and TEM study were later confirmed by Ye et al. [54]. In fact, the researchers determined that the optimal loading for nano- $\mathrm{MnO}_{2}$ supported $\mathrm{Ag}$ was $5 \mathrm{wt} \%$ [54]. From the TPR analysis, this sample resulted in having the lowest reducibility temperature, but due to the lack of data regarding the surface characterization, it is not possible to justify the reason for the decrease of catalytic activity at higher loadings. Similar results were obtained by Kim and Ryu; the researchers determined that the optimal loading on $\gamma-\mathrm{Al}_{2} \mathrm{O}_{3}$ supported $\mathrm{Ag}$ is $11 \mathrm{wt} \%$ [55]. Again, the lack of data regarding the physical characterization only allows speculations regarding the plateau of the catalytic performances described by the authors [55]. Nonetheless, a logical hypothesis would be that due to the increase of the crystallite size and the reduction of surface area and pore volume correlated with the increase of metal load the number of active sites will not vary significantly with the increase of Ag load.

Zhou et al. tested the performances of $\mathrm{Cu}-\mathrm{Mn}-\mathrm{Ag}$ mixed oxide deposited on cordite monolith [56]. During their tests a $\mathrm{Cu} / \mathrm{Mn}$ ratio of $1 / 1$ was kept constant, since such a ratio usually leads to optimal performances in VOCs oxidation $[57,58]$ while different Ag loadings were tested. It showed that an active phase loading of $21.2 \mathrm{wt} \%$ (with an $\mathrm{Ag} / \mathrm{Cu} / \mathrm{Mn}$ ratio of 13.8/43.1/43.1) produced the best removal efficiency of toluene $\left(0.89 \mathrm{vol} \%\right.$, space velocity $\left.10,000 \mathrm{~h}^{-1}\right)$ at $\mathrm{T}_{90}$ of $264^{\circ} \mathrm{C}$. Data suggested that, for a lower loading of $\mathrm{Ag}$, the reduction of active phase quantity reduces the number of active sites and consequently the removal efficiency could be reduced [56]. For higher loading, the accumulation of the active phase on the external layer of the monolith was detected with the formation of an inefficient monolith [56]. It is not clear if this last observation can be applied in the other reviewed experiments.

Particularly interesting are the tests held by Li and Gaillard on the electrochemical promotion of $\mathrm{Ag}$ based catalyst [59]. During this study, Li and Gaillard demonstrated that a thin film of $\mathrm{Ag}$ deposited on $\mathrm{Y}_{2} \mathrm{O}_{3}$ stabilized $\mathrm{ZrO}_{2}$ was able to oxidize $500 \mathrm{ppm}$ of toluene (flow speed $100 \mathrm{~mL} / \mathrm{min}$ ), achieving around $25 \%$ conversion at $330^{\circ} \mathrm{C}$ when a negative potential of $-3 \mathrm{~V}$ was applied [59]. The application of an external potential promotes the electrochemical pumping of $\mathrm{O}^{2-}$ on the catalyst surface; this effect favours the adsorption of oxygen and the oxidation of toluene [59]. The writer also reported that at low concentration of toluene $(100 \mathrm{ppm})$ the conversion to $\mathrm{CO}_{2}$ was lower, and it increased with the increase of the pollutant concentration (up to $1,200 \mathrm{ppm}$ ) [59]. This fact was correlated with the adsorption of oxygen on the catalyst surface; at low toluene concentration a large quantity of $\mathrm{O}_{2}$ is adsorbed on the catalyst, blocking the active sites and by consequence reducing the conversion efficiency [59]. By consequence, this catalyst is suitable to operate with low concentration of $\mathrm{O}_{2}$ (lower than 2\%) [59]. The authors also describe how the increase of the applied potential initially increases $\mathrm{Ag}$ activity until it reaches a plateau; any further increase of the applied potential will cause a decrease of the catalytic activity [59]. This fact is correlated with the adsorption of oxygen on the catalyst surface; in fact, an increase in the applied potential promotes the adsorption of oxygen, generating a competitive effect with the adsorption of toluene [59]. It is worth mentioning that the study does not define the conditions necessary to reach the complete oxidation of the selected pollutant.

As summarized in Tables 1 and 2, a temperature of 250$350^{\circ} \mathrm{C}$ is usually sufficient to achieve the complete oxidation of the selected pollutants with high concentration over various catalysts. Silver based catalysts appear to offer inferior performances for the removal of BTEX compared to other noble or transition metals.

Table 1 presents a summary of the catalytic performance reported in the reviewed literature. It has to be noted that the experimental reaction conditions especially the temperature might not be the same.

\section{Nonnoble Metal Oxide Based Catalyst}

Nonnoble metal oxides are cheaper than noble metals as active phase of catalysts and due to their effective catalytic capability are also often used for the removal of VOCs from flue gases. The most effective metals reported for this application are V, Cr, Mn, and Ce. Other metals, such as Fe, $\mathrm{Co}$, and Mo, were also studied but their catalytic performance as single metal oxide was relatively poorer. The catalytic capability of the abovementioned metal oxides is generally not as good as that of the noble metal based catalysts, but mixed metal oxides would be possible to achieve the comparable catalytic efficiency to noble metals, which would be discussed in the following section.

3.1.V Based Catalyst. V based catalysts were mostly prepared through incipient wetness to achieve a vanadia loading between 5 and $10 \mathrm{wt} \%$ on the selected support [73-75]. This metal was mainly applied for the removal of chlorinated VOCs. Krishnamoorthy et al. tested the oxidation of dichlorobenzene $(600 \mathrm{ppmv})$ on $\mathrm{V}_{2} \mathrm{O}_{5} / \mathrm{TiO}_{2}$ catalyst with different vanadium load [73], which showed that the increase in metal load improved the catalyst activity achieving $>90 \%$ conversion at around $470^{\circ} \mathrm{C}$ by the $5.8 \mathrm{wt} \%$ catalyst. These 
TABLE 1: Catalytic performance comparison of various noble metals loaded catalysts.

\begin{tabular}{|c|c|c|c|c|c|}
\hline Catalyst & $\begin{array}{c}\text { Active phase } \\
\text { concentration (wt\%) }\end{array}$ & $\begin{array}{l}\text { VOC concentration } \\
(\mathrm{ppm})\end{array}$ & VOC total conversion $\left({ }^{\circ} \mathrm{C}\right)^{1}$ & Gas flow ${ }^{2}$ & Publication year \\
\hline $\mathrm{Pt} / \mathrm{SDB}$ & 3 & Toluene 442 & 150 & $21,000 \mathrm{~h}^{-1}$ & $1998[25]$ \\
\hline $\mathrm{Pd} / \mathrm{HFAU}$ & 0.2 & o-Xylene 1,700 & Around 280 & $18,000 \mathrm{~h}^{-1}$ & $1999[31]$ \\
\hline $\mathrm{Au} / \mathrm{Fe}_{2} \mathrm{O}_{3}$ & 8.2 & Toluene 7,000 & Around 400 & $7.6 \times 10^{-3} \mathrm{molh}^{-1} \mathrm{~g}^{-1}$ & $2000[40]$ \\
\hline $\mathrm{Au} / \mathrm{CeO}_{2} / \mathrm{Al}_{2} \mathrm{O}_{3}$ & 2.50 & Benzene 250 & Around 280 & $9,700 \mathrm{~h}^{-1}$ & $2002[41]$ \\
\hline $\mathrm{Au} / \mathrm{Al}_{2} \mathrm{O}_{3}$ & 1.91 & Benzene 250 & Around 290 & $9,700 \mathrm{~h}^{-1}$ & $2002[41]$ \\
\hline $\mathrm{Pd} /$ zeolite & 2.3 & Benzene 10,000 & Around 250 & $60,000 \mathrm{~h}^{-1}$ & 2003 [37] \\
\hline $\mathrm{Au} / \mathrm{CeO}_{2}$ & 5.0 & Toluene 7,000 & Around 390 & $7.6 \times 10^{-3} \mathrm{molh}^{-1} \mathrm{~g}^{-1}$ & $2003[42]$ \\
\hline Ag/HY zeolite & 3.4 & Toluene 1,000 & 290 & $6000 \mathrm{~h}^{-1}$ & $2004[53]$ \\
\hline $\mathrm{Pt} /$ zeolite & 0.5 & o-Xylene 210 & Around 350 & $76 \mathrm{~mL} / \mathrm{min}$ & 2007 [27] \\
\hline $\mathrm{Ag} / \mathrm{Nano}-\mathrm{MnO}_{2}$ & 5 & Benzene 2,000 & Around 400 & $100 \mathrm{~mL} / \mathrm{min}$ & $2011[54]$ \\
\hline $\mathrm{Au} / 3 \mathrm{DOM} \mathrm{LaCoO}_{3}$ & 7.63 & Toluene 1,000 & Around 190 & $20,000 \mathrm{~h}^{-1}$ & $2013[43]$ \\
\hline $\mathrm{Pd} / \mathrm{CeTi}$ & 1.5 & Toluene 1,000 & Around 250 & $100 \mathrm{~mL} / \mathrm{min}$ & $2014[34]$ \\
\hline $\mathrm{Au} / \mathrm{CeTi}$ & 3 & Toluene 1,000 & Around 350 & $100 \mathrm{~mL} / \mathrm{min}$ & $2014[34]$ \\
\hline
\end{tabular}

${ }^{1}$ The temperatures were extracted from relevant figures given in the literature and exact values are difficult to be presented here.

${ }^{2}$ Due to the lack of dimension for the reactors used in literature, it is difficult to convert all the gas flow with the same units.

catalysts demonstrated a good stability over $100 \mathrm{~h}$ but were sensitive to the presence of water [73, 75]. During the stability test the presence of $\mathrm{Cl}$ on the catalyst surface was reported but it seemed not to affect the catalyst activity [75]. Krishnamoorthy et al. found that, due to the low V$\mathrm{Cl}$ bond energy $(121 \mathrm{~kJ} / \mathrm{mol})$, $\mathrm{Cl}$ could be easily removed from the catalyst surface with a consequent lower reaction temperature for the oxidation of VOCs without poisoning the catalyst [73]. This result explains the high activity of the vanadia sites for chlorinated VOCs [73]. Nonetheless, an issue with the application of this catalyst is the formation of $\mathrm{CO}$ as byproduct which accounted for $40-45 \%$ of the carbon balance and it is not influenced by the metal load, which may require additional control for its disposal $[73,75]$.

$\mathrm{VO}_{x} / \mathrm{TiO}_{2}$ was also studied for the removal of benzene (100 ppm, GHSV $37,000 \mathrm{~h}^{-1}$ ) [76]. The catalyst was able to remove around $60 \%$ of benzene at $300^{\circ} \mathrm{C}$, but vanadium oxide supported on sulphated $\mathrm{TiO}_{2}$ reached over $95 \%$ conversion at the same temperature and at over $300^{\circ} \mathrm{C}$ it reached a $100 \%$ conversion [76]. Various research groups reported that the catalytic activity is related to the vanadia-support interaction $[73,74,76]$. According to Krishnamoorthy and Amiridis, this interaction influences vanadia's redox properties resulting in lower activation energies [74]. XRD results showed that different supports produce a different degree of dispersions of the active phase and the $\mathrm{TiO}_{2}$ supported catalyst shows a well dispersed monolayer of the active phase, while other supports such as $\mathrm{Al}_{2} \mathrm{O}_{3}$ and especially $\mathrm{SiO}_{2}$ tend to form a poorly dispersed crystallite phase with a consequent decrease of the catalytic activity [76].

This type of catalyst seems suitable for pretreatment of flue gases containing chlorinated VOCs if incorporated with hydrophobic supports. However, it might need to be applied for the pretreatment of flue gas due to its high selectivity to produce $\mathrm{CO}$ as byproduct. The reducibility of both the active element and the support for this type of catalyst is still scarce. TPR test would be a feasible option to determine if the interaction of catalyst-support could increase the reactivity of the active phase or if $\mathrm{V}$, similar to $\mathrm{Au}$, could promote the activity of the selected support. The information derived from this step may benefit the selection of the optimum support for some certain application.

3.2. Cr Based Catalysts. Cr based catalysts have been tested on both chlorinated and nonchlorinated VOCs. Krishnamoorthy et al. reported that $\mathrm{Cr}$ based catalysts are highly active for VOCs removal which could achieve complete removal of dichlorobenzene $(600 \mathrm{ppm}$ at space velocity $25,000 \mathrm{~h}^{-1}$ ) at around $280^{\circ} \mathrm{C}$ [75]. The light-off temperature of this catalyst was higher than using vanadium, but it achieved the total oxidation at a lower temperature [76]. The similar activity of these two types of catalysts for chlorinated VOCs could be explained by the fact that the removal of $\mathrm{Cl}$ from the catalyst surface is not kinetically significant [75]. Similar to $\mathrm{V}$ and Pt based catalysts, the activity of $\mathrm{Cr}$ based catalyst got inhibited by the presence of water due to a competitive adsorption of water molecule on the active sites [75]. It was also reported that the catalytic activity was affected by different supports (i.e., $\mathrm{M}_{x} \mathrm{O}_{y} / \mathrm{TiO}_{2}>\mathrm{M}_{x} \mathrm{O}_{y} / \mathrm{Al}_{2} \mathrm{O}_{3}$ ) tested in this study, indicating the metal-oxygen-support bond is critical for this degradation reaction [75]. FTIR analysis suggested that the removal of $\mathrm{Cl}$ from the catalyst surface and its substitution with oxygen occur via nucleophilic mechanism, which is likely to be influenced by the support's nature [75]. The tests demonstrated that the $\mathrm{Cl}$ removal is the first reaction step, followed by the adsorption of the aromatic ring and its subsequent oxidation [75]. During their tests, for the identification of a proper support for the removal of chlorinated VOCs, Bertinchamps et al. achieved the complete conversion of $100 \mathrm{ppm}$ of benzene at $250^{\circ} \mathrm{C}$ for a $\mathrm{Cr}$ oxide catalyst supported on $\mathrm{TiO}_{2}$ [76]. XRD analysis revealed a good dispersion of the active phase on various supports 
TABLE 2: Non-noble metal based catalysts in the recent literature.

\begin{tabular}{|c|c|c|c|c|c|}
\hline Catalyst & $\begin{array}{c}\text { Active phase } \\
\text { concentration (wt\%) }\end{array}$ & $\begin{array}{l}\text { VOC concentration } \\
(\mathrm{ppm})\end{array}$ & $\begin{array}{c}\text { VOC total } \\
\text { conversion }\left({ }^{\circ} \mathrm{C}\right)^{1}\end{array}$ & Gas flow $^{2}$ & Publication year \\
\hline $\mathrm{Mn}_{x} \mathrm{Zr}_{y}$ & 50 & Toluene 3,500 & Around 250 & $60 \mathrm{~mL} / \mathrm{min}$ & $2004[60]$ \\
\hline $\mathrm{CuO} / \mathrm{Al}_{2} \mathrm{O}_{3}$ & 5 & Toluene 4,000 & Around 350 & $3,600 \mathrm{~mL} \mathrm{~h}^{-1} \mathrm{~g}^{-1}$ & $2004[61]$ \\
\hline $\mathrm{CuCsHY}$ & $1.3 \mathrm{Cu}, 5.5 \mathrm{Cs}$ & Toluene 800 & Below 450 & $24,200 \mathrm{~h}^{-1}$ & $2007[62]$ \\
\hline $\mathrm{LaCoO}_{3}$ & 20 & $\begin{array}{l}\text { Benzene } 1,700 \\
\text { Toluene } 1,700\end{array}$ & $\begin{array}{l}\text { Around } 450 \\
\text { Around } 350\end{array}$ & $60,000 \mathrm{~mL} \mathrm{~h}^{-1} \mathrm{~g}^{-1}$ & 2007 [63] \\
\hline $\mathrm{MnCu} / \mathrm{FeCr}$ Alloy & $\begin{array}{c}35(\mathrm{Mn} / \mathrm{Cu} \text { ratio } 1: 1) \\
\text { washcoating } \\
\text { solution }\end{array}$ & Toluene 265 & Below 350 & $10,000 \mathrm{~h}^{-1}$ & $2008[64]$ \\
\hline $\mathrm{MnO}_{x}-\mathrm{CeO}_{2}$ & 25 & Toluene 600 & Below 260 & $50 \mathrm{~cm}^{3} / \mathrm{min}$ & 2008 [65] \\
\hline $\mathrm{Cu} / \mathrm{MnO}_{x}-\mathrm{CeO}_{2}$ & 2.54 & Benzene 200 & 350 & $30,000 \mathrm{~mL} \mathrm{~h}^{-1} \mathrm{~g}^{-1}$ & $2008[66]$ \\
\hline $\mathrm{Cu}-\mathrm{Mn} / \mathrm{MCM}-41$ & Not reported & Toluene 3,500 & Around 350 & $60 \mathrm{~cm}^{3} / \mathrm{min}$ & $2008[67]$ \\
\hline $\mathrm{MnO}_{x} / \mathrm{Al}_{2} \mathrm{O}_{3}$ & 11.25 & Toluene 10000 & Around 380 & $100 \mathrm{~mL} / \mathrm{min}$ & $2009[68]$ \\
\hline $\mathrm{Mn}_{3} \mathrm{O}_{4}$ & Pure phase & Toluene 1,000 & Below 250 & $100 \mathrm{~cm}^{3} / \mathrm{min}$ & 2010 [69] \\
\hline $\mathrm{Ca} / \mathrm{Mn}_{3} \mathrm{O}_{4}$ & 0.5 & $\begin{array}{l}\text { Benzene 2,000 } \\
\text { Toluene 2,000 }\end{array}$ & $\begin{array}{l}\text { Around } 250 \\
\text { Around } 270\end{array}$ & $100 \mathrm{~cm}^{3} / \mathrm{min}$ & $2010[69]$ \\
\hline $\mathrm{Na}_{88} \mathrm{Al}_{88} \mathrm{Si}_{104} \mathrm{O}_{384}$ & Pure phase & o-Xylene 1,360 & Around 320 & $18,000 \mathrm{~h}^{-1}$ & $2010[70]$ \\
\hline $\mathrm{Cu}_{0.13} \mathrm{Ce}_{0.87} \mathrm{O}_{y}$ & Pure phase & Toluene 1,000 & Around 250 & $90,000 \mathrm{~h}^{-1}$ & $2011[21]$ \\
\hline $\mathrm{Cu}-\mathrm{Ce} / \mathrm{Al}_{2} \mathrm{O}_{3}$ & $15 \mathrm{Cu}, 75 \mathrm{Ce}$ & Toluene 1,000 & Around 320 & $200 \mathrm{~cm}^{3} / \mathrm{min}$ & $2011[71]$ \\
\hline $\mathrm{Mn}-\mathrm{Ce} / \mathrm{Al}_{2} \mathrm{O}_{3}$ & $30 \mathrm{Mn}, 40 \mathrm{Ce}$ & Toluene 1,000 & Around 320 & $200 \mathrm{~cm}^{3} / \mathrm{min}$ & $2011[71]$ \\
\hline $\mathrm{Cu}-\mathrm{Mn} / \mathrm{Al}_{2} \mathrm{O}_{3}$ & $10 \mathrm{Cu}, 60 \mathrm{Mn}$ & Toluene 1,000 & Below 300 & $200 \mathrm{~cm}^{3} / \mathrm{min}$ & $2011[71]$ \\
\hline CoMn/Activated Carbon & $20(\mathrm{Mn} / \mathrm{Co}$ ratio 1.5$)$ & $\begin{array}{c}\text { Toluene } 10,000 \\
\text { Ethylbenzene } 10,000 \\
\text { Benzene } 10,000\end{array}$ & $\begin{array}{l}>98.7 \% \text { at } 250 \\
>90 \% \text { at } 250 \\
<10 \% \text { at } 350\end{array}$ & $66,000 \mathrm{~mL} \mathrm{~h}^{-1} \mathrm{~g}^{-1}$ & $2015[72]$ \\
\hline
\end{tabular}

${ }^{1}$ The temperatures were extracted from relevant figures given in the literature and exact values are difficult to be presented here.

${ }^{2}$ Due to the lack of dimension for the reactors used in literature, it is difficult to convert all the gas flow with the same units.

except $\mathrm{SiO}_{2}$, which as mentioned before besides the surface is also highly correlated with the catalytic activity; this study demonstrated that the activity of $\mathrm{Cr}$ based catalyst depends on the nature of the support and not only on its surface area [76]. Chromium, supported on $\mathrm{MnCu}$ wash coated monolith, was also used to produce active element achieving complete conversion of toluene at below $350^{\circ} \mathrm{C}$ [64]. Even considering the good performances of $\mathrm{Cr}$ for the removal of a wide range of pollutants the low temperatures necessary for the complete oxidation, the use of this active phase is limited by its high toxicity and the environmental issues associated with its disposal and potential leakage. More tests would be necessary to determine the thermal stability and durability of these catalysts as these factors may limit their industrial application.

3.3. Mn Based Catalysts. $\mathrm{MnO}_{x}$ deposited on various supports were also studied for the removal of chlorinated VOCs and among different tested supports $\mathrm{MnO}_{x} / \mathrm{TiO}_{2}$ $\mathrm{Al}_{2} \mathrm{O}_{3}$ showed the highest activity [76-78]. Liu et al. achieved $97 \%$ removal of chlorobenzene $(1,300 \mathrm{ppm}$, space velocity $8,000 \mathrm{~h}^{-1}$ ) at $350^{\circ} \mathrm{C}$ using this catalyst, while the $\mathrm{TiO}_{2}$ supported one achieved $62 \%$ removal only under the same experimental conditions [78]. During the performance test, the catalytic activity increased for the first $10-20 \mathrm{~h}$ and then became stable for at least the next $52 \mathrm{~h}$ [77]. It was reported that no chlorinated byproducts were formed during this reaction [78]. The activity increase observed during the first hours was found due to the formation of chlorinated species of Mn by XPS analysis; the test also showed that $\mathrm{Cl}$ was introduced into the catalyst inside structure but Mn only got partially chlorinated [78]. It seems that the chlorinated species of $\mathrm{Mn}$ is more active and stable than the $\mathrm{MnO}_{x}$ in this type of catalyst [78]. In addition, the interaction between $\mathrm{Mn}$ and various supports including $\mathrm{TiO}_{2}, \mathrm{Al}_{2} \mathrm{O}_{3}$, and $\mathrm{SiO}_{2}$ played an important role in the catalyst's activity $[77,78]$. According to the TPR experimental results, the weak performances of the $\mathrm{Al}_{2} \mathrm{O}_{3}$ supported catalyst were due to the strong interaction of $\mathrm{MnO}_{x}-\mathrm{Al}_{2} \mathrm{O}_{3}$ which would reduce the quantity of reducible oxygen to only half of those available on the $\mathrm{TiO}_{2}$ supported catalysts $[77,78]$. Due to the higher activity and stability of chlorinated $\mathrm{Mn}$ for removal of these pollutants, it would be important to determine the optimum ratio of $\mathrm{MnCl}_{x} / \mathrm{MnO}_{x}$ which could achieve the best activity and stability of these catalysts and optimize their synthesis condition.

It has been reported recently that some nonnoble metal oxides based catalysts show comparable or even superior catalytic ability to those noble metals contained catalysts [72, 79]. Zhou et al. found that CoMn mixed oxide supported on activated carbon $(\mathrm{AC})$ is more efficient than Pd or Au for the removal of toluene $(10,000 \mathrm{ppm})$ which could achieve $>98 \%$ 
removal at $250^{\circ} \mathrm{C}$ [72]. The properties of this type of catalyst, including low temperature reducibility, high surface area, and good porosity, promoted its catalytic capability for the oxidation of phenyl VOCs. Another important parameter affecting the catalyst's activity is the calcination temperature, which could influence the degree of crystallization of the metal. A low calcination temperature produces small particles of the active phase in a less crystalline structure, which influences the number of active sites on the catalysts [72]. The CoMn/AC oxide catalyst was stable over $720 \mathrm{~h}$ at $240^{\circ} \mathrm{C}$ and it was also highly active for the removal of ethylbenzene $(10,000 \mathrm{ppm}$, flow rate $55 \mathrm{~mL} / \mathrm{min}$ ) achieving over $90 \%$ conversion at $250^{\circ} \mathrm{C}$ [72]. However, this mixed oxide showed a low activity for benzene and it removed less than $10 \%$ at $350^{\circ} \mathrm{C}$ [72]. The difference in activities could be attributed to the different natures of the interested pollutants. The ionization potential of toluene and ethylbenzene is lower than that of benzene when oxidized on this type of catalyst [72]. Benzene is a nonpolar molecule with a symmetrical structure and a high structural stability and is more difficult to get absorbed and thermally degraded [72].

A number of studies have revealed that the activity of Mn based catalyst mostly depends on the metal state of oxidation which could change the reduction temperature of the prepared catalyst and in consequence the catalyst's activity $[65,69,80]$. Genuino et al. reported that the activity of this catalyst was highly affected by the concentration of $\mathrm{Mn}^{3+}$ and $\mathrm{Mn}^{4+}$ [80] and $\mathrm{Mn}^{3+}$ showed to be the most active in their study $[65,69,80]$. This observation was confirmed by Delimaris and Ioannides [65]. In their experiment, it was found that the most efficient $\mathrm{Mn}$ based catalysts for the removal of toluene ( $600 \mathrm{ppm}$ space velocity $30,000 \mathrm{~h}^{-1}$ ) was $\mathrm{Mn}_{x} \mathrm{Ce}_{1-x}$ mixed oxide, which achieved a complete conversion at below $260^{\circ} \mathrm{C}$ but did not contain $\mathrm{Mn}^{4+}$ sites from XRD analysis [65]. Doped with different elements such as $\mathrm{K}, \mathrm{Ca}$, or $\mathrm{Mg}$, the catalysts could decrease the optimum oxidation temperature of the selected pollutants [69]. It should be noted that the support can also influence the catalyst reducibility. TPR analysis by Pozan showed that two peaks at 392 and $463^{\circ} \mathrm{C}$, corresponding to the reduction $\mathrm{MnO}_{2} \rightarrow \mathrm{Mn}_{2} \mathrm{O}_{3}$ and $\mathrm{Mn}_{2} \mathrm{O}_{3} \rightarrow \mathrm{MnO}$, got shifted to lower temperatures when $\mathrm{Mn}$ was supported on $\gamma-\mathrm{Al}_{2} \mathrm{O}_{3}$ [81].

Kim and Shim found that the doped and nondoped catalysts had similar BET and XRD profiles while the significant difference was observed with the TPR profile where a shoulder peak appeared in an interval of temperature between 227 and $234^{\circ} \mathrm{C}$ [69]. The increase of catalytic activity for such type of catalyst is believed to be relevant to the presence of this shoulder peak [69]. The addition of promoting atoms also increases the binding energy of manganese oxide, which would help increase the number of defect-oxide or hydroxyllike groups on the Mn surface [69]. These groups show a higher mobility of the lattice oxygen and consequently improve the catalyst activity [69]. Morales et al. reported that the addition of small amount of $\mathrm{Cu}$ produced a similar effect, which reduced the crystalline structure of $\mathrm{Mn}$ to increase the number of oxygen vacancies and the mobility of the lattice oxygen [82]. Due to this property, $\mathrm{Cu}$ is often added to other metals and its presence seems to increase the activity of both catalyst and support $[66,83]$. Manganese mixed oxides containing $\mathrm{Zr}$ proved to be effective for both chlorinated VOCs and BTEX $[60,84] . \mathrm{Mn}_{0.4} \mathrm{Zr}_{0.6} \mathrm{O}_{2}$ achieved a complete oxidation of 1,2-dichloroethane and trichloroethylene at $450^{\circ} \mathrm{C}$ and $550^{\circ} \mathrm{C}$, respectively [84], while $\mathrm{Mn}_{x} \mathrm{Zr}_{y}$ completely oxidized a synthetic gas containing $3,500 \mathrm{ppm}$ of toluene at a temperature lower than $300^{\circ} \mathrm{C}[60]$.

In addition, unsupported manganese synthesized using different methods has also been studied by being mixed with another metal to acquire the required catalytic properties for the removal of BTEX $[65,69,71,72]$. The advantage of these catalysts seems obvious that a much higher concentration of Mn could be achieved and the desired size could be controlled by different processes; however, the lack of supports may negatively affect the surface area, dispersion of active elements, and hydrophobic ability.

3.4. Ce Based Catalysts. As reported earlier, Ce has been often used as part of a mixed oxide catalyst $[65,66,71]$. This metal was found to be an excellent promoter or support for a more active phase due to its excellent oxygen storage capability [85]. TPR tests showed a shift in the bulk oxygen reduction temperature of $\mathrm{CeO}_{2}$ from around $580^{\circ} \mathrm{C}$ for the pure oxide to around $430^{\circ} \mathrm{C}$ and $360^{\circ} \mathrm{C}$ for the $\mathrm{MnO}_{x}-\mathrm{CeO}_{2}$ and $\mathrm{Cu} / \mathrm{MnO}_{x}-\mathrm{CeO}_{2}$ mixed oxide catalysts, respectively [66]. It has been mentioned before that the presence of copper could promote the mobility of the lattice oxygen of the other oxides so as to improve their catalytic activity [82]. Delimaris and Ioannides also reported an increase of the BET surface area of the Mn-Ce mixed oxide catalyst produced by the urea-nitrate combustion method compared to the pure oxide [65]. This observation may imply that the addition of small quantity of $\mathrm{Mn}$ to $\mathrm{Ce}$, or vice versa, helped control the crystallite growth while preserving the pore structure [65]. In addition, XRD studies also found a decrease of the lattice constant of $\mathrm{Ce}$ in presence of $\mathrm{Mn}$ [65]. Saqer et al. also reported that $\mathrm{CeO}_{2}$ alumina supported catalysts usually require high temperatures to achieve a complete conversion of the considered pollutants, though they are known for being active at low temperatures [71]. This catalyst, when supported on $\gamma-\mathrm{Al}_{2} \mathrm{O}_{3}$, presented a better dispersion of the active phase and stronger reactivity [71]. During that study the prepared $\mathrm{Cu}-\mathrm{Ce}$ and $\mathrm{Mn}$-Ce mixed oxide could achieve the complete conversion of toluene $(1,000 \mathrm{ppm})$ at around 350 and $325^{\circ} \mathrm{C}$, respectively, which were much lower compared to $450^{\circ} \mathrm{C}$ required using the pure ceria [71]. Zhou et al. studied Ce nanostructures catalytic performances and they found that the nanostructure morphology can influence its behaviour and activity for the selected pollutants [85]. The catalyst was prepared through hydrothermal crystallization in the form of nanorods and nanocubes [85]. The TEM analysis revealed that the two catalysts differed not only in shape but also in crystal size, dispersion, and orientation, most of which were heavily affected by synthesis temperature [85]. The nanocubes showed a uniform particle size of $8 \mathrm{~nm}$, while the nanorods ranged from 7 to $14 \mathrm{~nm}$ [85]. Though the nanocubes showed a smaller particle scale, XRD characterization found that the nanorods possessed a more amorphous structure, which 
could lead to a higher quantity of structural defect property with a consequent stronger catalytic activity [85]. TPR data supported the above inference by that nanorods showed more intense reduction peaks at a slightly lower temperature when compared to the nanocube structure, which further confirmed a higher dispersion of reducible species on this catalyst surface [85]. The catalysts activity also depends on their oxygen storage capability since the desorbed oxygen can form active oxygen species that greatly contribute to the catalyst activity. The $\mathrm{CeO}_{2}$ nanorods showed a much higher storage capability [85]. Azalim et al. investigated the performance of $\mathrm{Zr}_{0.4} \mathrm{Ce}_{0.6-x} \mathrm{Mn}_{x} \mathrm{O}_{2}$ mixed oxide [86]. It was found that increasing the $\mathrm{Mn}$ load improved the textural and redox properties, but higher $x$ value lowered the activity due to the different rate of the redox couples $\mathrm{Ce}^{4+} / \mathrm{Ce}^{3+}$ and $\mathrm{Mn}^{4+} / \mathrm{Mn}^{3+}[86]$.

Ce based catalyst has been extensively studied for the oxidation of VOCs which showed promising properties in most of reported applications. It is worth mentioning that the reviewed literature does not include the use of this catalyst for the removal of chlorinated VOCs and no information regarding the coke formation on it was discussed.

Table 2 listed those recently developed nonnoble metal based catalysts and their respective conversion efficiency of interested VOCs.

\section{Perovskites Catalyst}

Perovskites catalysts were widely studied for various applications and these compounds show high thermal stability and activity [87]. Perovskites can be generally presented by the formula $A_{1} A_{2} B_{1} B_{2} O_{3}$, where $A_{1}$ is chosen among lanthanides, $A_{2}$ is an alkaline earth metal, $B_{1}$ and $B_{2}$ are transition metals. It should be noted that under suitable conditions perovskites can achieve activity similar to noble metal based catalyst despite their extremely low surface area typically in the range of $3-5 \mathrm{~m}^{2} \mathrm{~g}^{-1}$ [87]. The low surface area is believed to be correlated with the preparation method which normally requires long exposure time at high temperatures [87]. How to lower the synthesis temperature to increase the BET area is one of the main focuses for the perovskites, since this parameter is very critical to the catalytic activity [87]. Different preparation methods have been used in order to increase the surface area including coprecipitation and solgel process. The sol-gel from citrate precursor appeared to be the most common synthetic methodology adopted in the literature reviewed. A selected quantity of nitrate precursor solutions was mixed and citric acid was added, and then the prepared solution was dried, grinded, and calcined $[63,88$, 89]. Sinquin et al. investigated the effect of different precursors in the synthesis of perovskites [90] and found that the use of metals or metallic nitrates allows the removal of the ligand as nitrate vapor while the use of metallic chlorine is not ideal since this ligand cannot be easily removed from the solution [90]. The presence of $\mathrm{Cl}$ induced the formation of impurities in the final product, which may block the synthesis of the perovskite by forming chlorinated complex with the involved metals [90]. Alifanti et al. synthesized $\mathrm{LaCoO}_{3}$ perovskite on $\mathrm{Ce}_{1-x} \mathrm{Zr}_{x} \mathrm{O}_{2}(x=0-0.3)$, for which the support was prepared by complexation with citric acid and calcined at $700^{\circ} \mathrm{C}$ for $6 \mathrm{~h}$ [63]. The support was successively impregnated with excess aqueous solution of $\mathrm{La}$ and Co nitrates (La/Co ratio 1/1) and citric acid, and the surface area achieved was between 23.6 and $22.7 \mathrm{~m} \mathrm{~g}^{2} \mathrm{~g}^{-1}$ for the 10 and $20 \mathrm{wt} \%$ supported catalysts, respectively, and $11.3 \mathrm{~m}^{2} \mathrm{~g}^{-1}$ for the unsupported perovskite [63]. The same study reported that $\mathrm{LaCoO}_{3} / \mathrm{Ce}_{0.9} \mathrm{Zr}_{0.1} \mathrm{O}_{2}$ (20 wt\%) achieved the best performances completely oxidizing $1700 \mathrm{ppm}$ of benzene and toluene (air flow $100 \mathrm{~mL} / \mathrm{min}$ ) at around 450 and $350^{\circ} \mathrm{C}$, respectively [63]. It also found that the bulk perovskite achieved a total conversion of benzene at a similar temperature while a higher temperature of $450^{\circ} \mathrm{C}$ was needed to fully oxidize toluene [63]. These results appear to confirm the ones previously achieved by Spinicci et al. for the conversion of benzene ( $250 \mathrm{ppm}$, space velocity $14,100 \mathrm{~h}^{-1}$ ), using unsupported $\mathrm{Mn}$ and Co based perovskites [88]. Hosseini et al. were recently able to synthesize bulk $\mathrm{Cu}, \mathrm{Cr}$, and $\mathrm{Mn}$ based perovskites with a surface area ranging from 15 to $11.3 \mathrm{~m}^{2} \mathrm{~g}^{-1}$ dependent on the composition, and some deviation from the pure rhombohedral structure typically for $\mathrm{LaCoO}_{3}$ perovskites was observed by XRD analysis [89]. The TPR tests revealed that the metal dopant promoted the reduction of $\mathrm{Co}$ in the perovskites leading to a consequent increase of the catalytic activity [89]. It has been reported that $\mathrm{Cr}^{3+}$ in $\mathrm{LaCrO}_{3}$ structure is highly stable and hence cannot be reduced under the condition applied during the study; on the contrary the $\mathrm{Mn}$ doped perovskites showed the sharpest reduction peaks [89]. $\mathrm{LaMn}_{x} \mathrm{Co}_{1-x} \mathrm{O}_{3}(x=0.1$, $0.25,0.5)$ presented the most active capability for the removal of toluene $\left(2,000 \mathrm{ppm}\right.$, space velocity $\left.5,000 \mathrm{~h}^{-1}\right)$ achieving $>99 \%$ conversion at around $400^{\circ} \mathrm{C}$, which is in agreement with TPR results [89].

Perovskites were also tested under the condition with $\mathrm{SO}_{2}$ presence. Huang et al. prepared $\mathrm{La}_{0.8} \mathrm{Cu}_{0.2} \mathrm{MnO}_{3}$ and $\mathrm{La}_{0.8} \mathrm{Sr}_{0.2} \mathrm{MnO}_{3}$ for the removal of toluene $(6000 \mathrm{ppm}$ GHSV $5000 \mathrm{~h}^{-1}$ ) in presence of dodecyl mercaptan and both catalysts lost activity over time due to the formation of $\mathrm{CuSO}_{4}$ or $\mathrm{SrSO}_{4}$ [91]. The activity decreased with the increase of $\mathrm{SO}_{2}$ concentration and dropped to around $30 \%$ and $20 \%$ of toluene conversion over $150 \mathrm{~h}$ operations with $\mathrm{SO}_{2}$ of $60 \mathrm{ppm}$ for $\mathrm{La}_{0.8} \mathrm{Sr}_{0.2} \mathrm{MnO}_{3}$ and $\mathrm{La}_{0.8} \mathrm{Cu}_{0.2} \mathrm{MnO}_{3}$, respectively [91]. However, both catalysts showed a good stability over $200 \mathrm{~h}$ in presence of dichloromethane and the $\mathrm{Sr}$ catalyst achieved the best performance maintaining a toluene conversion over 95\% [91].

From the reviewed literature perovskite based catalysts appear to offer high catalytic activity, selectivity, durability, and resistance to poisoning. The use of different supports can help to balance the natural lack of surface area property of this class of compounds so as to improve the catalytic activity. The supports need to possess a high thermal stability in order to withstand the harsh conditions involved in the synthesis of the perovskite.

\section{Spinel Catalysts}

Spinel based catalysts have been reported to be highly active for the catalytic oxidation of hydrocarbons. This class of 
mixed oxide shows an $\mathrm{AB}_{2} \mathrm{O}_{4}$ composition and a defect-rich crystal structure. Due to the peculiarity of the desired crystalline structure and the need of maintaining a high surface area, the preparation method plays a fundamental role in the synthesis of spinel catalysts.

Zavyalova et al. synthesized CoCr or CoCu spinels using the gel-combustion method, which applied nitrate precursors and glycine or glycerine as fuels [92]. XRD results showed that the addition of ammonium nitrate as additional combustion aid prevented the formation of small quantity of single oxides $(10-25 \mathrm{wt} \%)$ and the use of glycerine led to the formation of $\mathrm{Co}_{0.7}^{\mathrm{II}} \mathrm{Cr}^{\mathrm{II}}{ }_{0.3} \mathrm{Cr}^{\mathrm{III}}{ }_{1.6} \mathrm{Co}^{\mathrm{III}}{ }_{0.4} \mathrm{O}_{4}$ and $\mathrm{Cu}_{0.95} \mathrm{Co}_{2.05} \mathrm{O}_{4}$ instead of the normal $\mathrm{CoCr}_{2} \mathrm{O}_{4}$ and $\mathrm{CuCo}_{2} \mathrm{O}_{4}$ obtained using glycine as a fuel [92]. XRD data also showed that the final product slightly differed from the conventionally synthesized catalyst using metal nitrate decomposition in air at $600^{\circ} \mathrm{C}$, which would contain $\mathrm{Co}^{\mathrm{II}} \mathrm{Co}^{\mathrm{III}}{ }_{0.4} \mathrm{Cr}_{1.6} \mathrm{O}_{4}$ and a $20 \%$ of free oxide for $\mathrm{CoCr}$ spinel or $66 \% \mathrm{Co}_{3} \mathrm{O}_{4}$ and $34 \% \mathrm{CuO}$ for the $\mathrm{CuCo}$ spinel [92]. Apparently the different composition can be explained by the solid-solid interaction in the metal mixture during the complexation stage which allows the formation of a pure phase composite at much milder temperatures (solution heated between 60 and $180^{\circ} \mathrm{C}$ ) [92]. The fuel/oxidizer (F/O) ratio also influences structural, redox, and catalytic properties of the spinel [93]. The F/O ratio affects the heating temperature and the evolution of gases from the solution to influence the catalyst morphology [93]. Hammiche-Bellal et al. synthesized $\mathrm{CoFe}_{2} \mathrm{O}_{4}$ spinels by coprecipitation method using chloride or nitrate precursor and XRD results showed that different precipitating agents could influence the composition of the final product [94]. It was reported that higher calcination temperature would lead to better crystallization and positively affect the lattice parameter, which might be due to the formation of oxygen rich spinels [94]. ZnAl spinels were also prepared via unconventional coprecipitation from nitrate precursors and its thermal stability was evaluated for temperature ranging from 550 up to $1,050^{\circ} \mathrm{C}$; the XRD analysis of the tested samples showed a crystallite growth from 3 to $13 \mathrm{~nm}$ with the increasing temperature [95]. As expected, the surface area and the pore volume decreased with the increase of calcination temperature [95]. BET measurement also implied that the adsorption-desorption isotherms profiles could be influenced by the calcination temperature due to the changes imposed to the catalyst morphology [95]. Castaño et al. prepared $\mathrm{MnMgAlO}_{x}$ by gel combustion using nitrate precursor and glycine as combustion agent for the removal of toluene $(600 \mathrm{ppm}$, flow rate $280 \mathrm{~mL} / \mathrm{min})$, and the catalyst synthesized with a $\mathrm{F} / \mathrm{O}$ ratio of 0.56 showed the best performance achieving the complete oxidation of toluene at $300^{\circ} \mathrm{C}$ [93]. Cu-Mn spinels were also synthesized by Behar et al. for the removal of toluene $(1,000 \mathrm{ppm}$ flow rate $100 \mathrm{~mL} / \mathrm{min}$ ) [96]. The catalyst was prepared using sodium alginate and metal chlorides as precursors and achieved a complete conversion of toluene at $270^{\circ} \mathrm{C}$ [96]. The researcher simulated the experimental data using the Mars-van Krevelen model and the result indicated that the oxidation of toluene on this catalyst followed a two-step mechanism: the toluene oxidation on the lattice oxygen and followed by the reoxidation of the reduced metal oxide [96]. In addition, this class of mixed oxides with spinel structure could also be used as a support for hydrocarbon removal catalyst [95]. To sum up, spinels presented a high catalytic activity, thermal stability, and durability in the experimental condition reported from the reviewed literature.

\section{Dual Functional Adsorbent-Catalysts}

Dual functional adsorbent-catalysts appear to be a costeffective alternative to other classes of catalysts, which could be used to treat VOCs in two steps:

(a) Preconcentration: the pollutants are adsorbed from the flue gas onto the support surface.

(b) Temperature swing: during this step the temperature get increased to cause the pollutants desorbed. This step allows the adsorbent regenerated and the catalytic oxidation of organic pollutants.

It is clear that the adsorbent properties of the support would be as important as the catalytic activity of the active phase. Hence, improving the adsorbent's properties including surface area, pores size and distribution, and surface morphology to strengthen its adsorption capacity while maintaining its strong catalytic activity would be a challenging task for the synthesis of such type of catalysts.

Various materials have been used to prepare dual functional adsorbent-catalysts. Brazlauskas and Kitrys prepared a sandwich type $\mathrm{CuO}$ /zeolite adsorbent-catalyst which was for the removal of alcohol compounds [97]. This catalyst maintained active for 120-day operation for the effective oxidation of alcohols in the temperature range between 100 and $350^{\circ} \mathrm{C}$. Byproducts including propanal, propane, propene, glycidol, and dimethylketene were formed at low temperatures but they disappeared once the reaction temperatures were over $280^{\circ} \mathrm{C}$ [97]. Kolade et al. synthesized monolith structure made of Pd supported on active carbon as adsorptive catalytic reactor for the removal of 3,000 ppm of ethane [98]. This structure provides high surface area, low pressure drop, and low resistance to the transport of particulate and was able to maintain high VOC conversion (air containing 2,500 ppm of toluene) while preventing thermal loss [98]. An integrated process was reported for VOCs oxidation by Roland et al. using Pt-NaY zeolite catalyst with the assistance of radiofrequency energy to produce a selective dielectric heating [99]. It seems that complete oxidation of toluene was achieved as only $\mathrm{CO}_{2}$ and $\mathrm{H}_{2} \mathrm{O}$ were released and detected during the regeneration process at a temperature of $375^{\circ} \mathrm{C}$ [99]. Urbutis and Kitrys prepared $\mathrm{CuO}-\mathrm{CeO}_{2} / \mathrm{NaX}$ for the removal of BTX using the temperature swing. The concentration of benzene, toluene, and xylenes was $800 \mathrm{mg} \mathrm{m}^{-3}, 850 \mathrm{mg} \mathrm{m}^{-3}$, and $450 \mathrm{mg} \mathrm{m}^{-3}$, respectively. The oxidation reactions were exothermic and the temperature rose up to around $550^{\circ} \mathrm{C}$ and achieved BTX removal efficiency of $99.3 \%, 99.8 \%$, and $77.5 \%$, respectively [22]. It is clear that a wide variety of active phases and supports can be used to produce dual functional catalysts; this variety potentially makes the dual functional catalyst the most flexible class reviewed. It has to be noted that to produce 
an effective dual function catalyst the properties of both the supports and active phases need to be carefully examined and then tested together as a unit in order to produce the desired adsorptive and catalytic capabilities.

Nonetheless, these catalysts also have disadvantage of operating in different processes with different temperature requirements compared to the other catalysts. The temperature inside the catalytic reactor needs to be initially low in order to allow the adsorption of the pollutants onto the porous substrate as at high temperatures the pollutants will be released from the porous substrate. For the second step, the temperature needs to increase to allow the oxidation of the pollutants and to regenerate the adsorptive property of the porous substrate. The limit of adsorption and the competitive effect of the involved pollutants need to be carefully investigated in order to avoid their release into the environment.

\section{Effect of Water}

Water is often contained in flue gases emitted from various industries and is also one of the products of the oxidation of VOCs. Water can cause dual effects on catalysts to act as either a poison or a promoter. $\mathrm{Wu}$ and Chang reported that the use of a hydrophobic support could produce better result in presence of moisture [25]. The Pt/SDB catalyst showed a $100 \%$ conversion of $90 \mathrm{ppm}$ of toluene at $150^{\circ} \mathrm{C}$, while different and less hydrophobic supports as Pt/AC01 and $\mathrm{Pt} / \mathrm{AC} 03$ required $180-200^{\circ} \mathrm{C}$ for the complete oxidation. This redox mechanism also suggested that the VOC oxidation could be enhanced by the removal of the produced water [25]. The inhibition effect could be explained by steric hindrance of the water molecule [70]. Beauchet et al. reported the removal of isopropanol and o-xylene mixture $(1,360 \mathrm{ppm}$ for each VOC, flow rate $75 \mathrm{~mL} / \mathrm{min}$ ) over basic NaX zeolite under 33\% relative humidity $\left(11,000 \mathrm{ppm}_{2} \mathrm{O}\right)$ [70]. It was observed that the isopropanol initially adsorbed on the catalysts totally desorbed and a partial desorption of o-xylene $\left(1.41 \times 10^{-4} \mathrm{~mol} \mathrm{~g}^{-1}\right.$ remained absorbed) occurred. The effect could be attributed to a competitive effect or by a steric hindrance at the pores apertures where isopropanol and o-xylene got absorbed on different sites due to their polarity difference [70]. On the contrary, Krishnamoorthy et al. reported that the humidity had a promoting effect for the removal of 1,2-dichlorobenzene $\left(660 \mathrm{ppm}\right.$, space velocity $25,000 \mathrm{~h}^{-1}$ ) over $\mathrm{Co}_{3} \mathrm{O}_{4} / \mathrm{TiO}_{2}$ [75] The presence of water could remove $\mathrm{Cl}^{-}$from the active sites previously blocked by $\mathrm{Cl}^{-}$so as to prevent the deactivation of the catalysts [75]. It seems that the effect of water should always be carefully evaluated upon the selection of catalyst type and the nature of the VOCs to be targeted.

\section{Coke Formation}

The formation of carbonaceous compounds (coke) often occurs during VOCs oxidation, which could deposit in the catalyst pores and surface to block the active site and lower the activity.

Guisnet et al. tested the effect of the reaction temperature on the coke formation. During the study Pd supported on HFAU zeolite ( $\mathrm{Si} / \mathrm{Al}$ ratio 17$)$ was used to oxidize a concentration of $1,700 \mathrm{ppm}$ (flow rate $86 \mathrm{~mL} / \mathrm{min}$ ) of oxylene [31] at temperature between $150^{\circ} \mathrm{C}$ and $320^{\circ} \mathrm{C}$. The formation of coke was reported for temperature below $290^{\circ} \mathrm{C}$. The percentage of coke on the catalyst surface increased with the temperature until $200^{\circ} \mathrm{C}$ and then decreased until a complete removal at around $330^{\circ} \mathrm{C}$ [31]. The temperature also influenced the coke composition. It was found that the products of incomplete combustion at $150^{\circ} \mathrm{C}$ were mostly aromatic hydrocarbons ( $65 \mathrm{wt} \% \mathrm{ca}$.) while at over $200^{\circ} \mathrm{C}$ mostly oxygenated hydrocarbons were produced [31]. Dégé et al. also reported that the support characteristics influenced the coke formation too. Under the same experimental conditions, the increase of $\mathrm{Si} / \mathrm{Al}$ ratio reduced the number of acidic sites and lowered the formation of coke, which was believed to be associated with the negative effect of the sites acidity on the Pd reducibility [32]. The increase of time on stream also reduced the coke formation [31,32]. Beauchet et al. tested the activity of different zeolites ( $\mathrm{NaX}, \mathrm{CsX}$, and acidic zeolite $\mathrm{HY}$ ) to remove $1,360 \mathrm{ppm}$ of isopropanol or $210 \mathrm{ppm}$ of o-xylene (flow rate $75 \mathrm{~mL} / \mathrm{min}$ ) [27]. It was reported that at $200^{\circ} \mathrm{C}$ $\mathrm{NaX}$ activity was low due to a fast deactivation while $\mathrm{HY}$ coke content after $5 \mathrm{~h}$ reaction was $12 \mathrm{wt} \%$ [27]. Metal doping promoted the oxidation of organic pollutants and reduced the coke formation [27].

\section{Summary and Outlook}

Catalytic oxidation is deemed to be a very effective route for the abatement of VOCs emitted from various industries. Different categories of catalysts including noble metal, nonnoble metal oxide, perovskites, spinel, and dual functional adsorbent-catalysts have been reviewed. The type of active elements, particle size, and the nature of the supports including their porosity and acid-base properties could influence to a various extent catalytic performance of catalysts. Addition of water was proved to inhibit the oxidation of VOCs over those catalysts with hydrophilic surface as the moisture could cloak to greatly reduce their reactivity; from this perspective, hydrophobic supports could represent an alternative. The additional dopants or promoters such as $\mathrm{Ce}, \mathrm{Fe}$, and $\mathrm{Mn}$ on noble metal based catalysts were reported to increase the catalytic activity due to their greater oxygen storage capacity. In addition, the chlorine poisoning and coke formations effects were also briefly discussed.

Given that continuously tightening VOCs emission regulations are bringing new challenges to the VOCs catalytic control technologies, innovations are needed in designing of more durable and selective catalysts. Research strategies for the next few years may have to focus on the following few points:

(1) Research emphasis on the structure-activity relationships, reaction mechanism, stability of the catalysts, and solutions to possible inhibition effects.

(2) Modeling and prediction of destruction efficiency for any given reactor setup, which could be applied in the selection of the optimum reactor type for specific application. 
(3) Exploring coupling technology of heterogeneous catalysis with other assisting processes such as plasma to enhance the removal efficiency in a more costeffective way.

\section{Competing Interests}

The authors declare that there are no competing interests regarding the publication of this paper.

\section{Acknowledgments}

The authors acknowledge the financial support from the International Doctoral Innovation Centre, Ningbo Education Bureau, Ningbo Science and Technology Bureau, China's MoST, and The University of Nottingham. This work was also partially supported by Natural Science Foundation of China (41303091), Zhejiang Provincial Applied Research Program for Commonweal Technology (2015C33011), Strategic Priority Research Program (B) of the Chinese Academy of Sciences (XDB05020403), Ningbo Municipal Natural Science Foundation (2014A610096), Ningbo Municipal Key Project (2012B10042), and Open Fund by Jiangsu Key Laboratory of AEMPC (KHK1204 \& KHK1304).

\section{References}

[1] The European Parliament and The Council of the European Union, "Directive 2004/42/CE of the European Parliament and of the Council of 21 April 2004 on the limitation of emissions of volatile organic compounds due to the use of organic solvents in certain paints and varnishes and vehicle refinishing products and amending Directive 1999/13/EC," Official Journal of the European Union, vol. L 143, pp. 87-96, 2004, http://faolex.fao.org/docs/pdf/eur43014.pdf.

[2] Y. D. J. T. Houghton, D. J. Griggs, M. Noguer et al., Climate Change 2001: The Scientific Basis, Cambridge University Press, New York, NY, USA, 2001.

[3] H. Guo, S. C. Lee, L. Y. Chan, and W. M. Li, "Risk assessment of exposure to volatile organic compounds in different indoor environments," Environmental Research, vol. 94, no. 1, pp. 5766,2004

[4] C.-W. Lee, Y.-T. Dai, C.-H. Chien, and D.-J. Hsu, "Characteristics and health impacts of volatile organic compounds in photocopy centers," Environmental Research, vol. 100, no. 2, pp. 139-149, 2006.

[5] J. A. Zhou, Y. You, Z. P. Bai, Y. D. Hu, J. F. Zhang, and N. Zhang, "Health risk assessment of personal inhalation exposure to volatile organic compounds in Tianjin, China," Science of the Total Environment, vol. 409, no. 3, pp. 452-459, 2011.

[6] N. Ramírez, A. Cuadras, E. Rovira, F. Borrull, and R. M. Marcé, "Chronic risk assessment of exposure to volatile organic compounds in the atmosphere near the largest Mediterranean industrial site," Environment International, vol. 39, no. 1, pp. 200-209, 2012.

[7] C. Jia and J. Foran, "Air toxics concentrations, source identification, and health risks: an air pollution hot spot in southwest Memphis, TN," Atmospheric Environment, vol. 81, pp. 112-116, 2013.
[8] C. Liaud, N. T. Nguyen, R. Nasreddine, and S. Le Calvé, "Experimental performances study of a transportable GC-PID and two thermo-desorption based methods coupled to FID and MS detection to assess BTEX exposure at sub-ppb level in air," Talanta, vol. 127, pp. 33-42, 2014.

[9] Y. J. Zhang, Y. J. Mu, F. Meng et al., “The pollution levels of BTEX and carbonyls under haze and non-haze days in Beijing, China," Science of the Total Environment, vol. 490, pp. 391-396, 2014.

[10] F. F. Liu, C. Peng, and J. C. Ng, "BTEX in vitro exposure tool using human lung cells: trips and gains," Chemosphere, vol. 128, pp. 321-326, 2015.

[11] A. B. Ross, J. M. Jones, S. Chaiklangmuang et al., "Measurement and prediction of the emission of pollutants from the combustion of coal and biomass in a fixed bed furnace," Fuel, vol. 81, no. 5, pp. 571-582, 2002.

[12] A. J. Buczynska, A. Krata, M. Stranger et al., "Atmospheric BTEX-concentrations in an area with intensive street traffic," Atmospheric Environment, vol. 43, no. 2, pp. 311-318, 2009.

[13] M. Saidi, M. Parhoudeh, and M. R. Rahimpour, "Mitigation of BTEX emission from gas dehydration unit by application of Drizo process: a case study in Farashband gas processing plant; Iran," Journal of Natural Gas Science and Engineering, vol. 19, pp. 32-45, 2014.

[14] A. Berenjian, N. Chan, and H. J. Malmiri, "Volatile organic compounds removal methods: a review," American Journal of Biochemistry and Biotechnology, vol. 8, no. 4, pp. 220-229, 2012.

[15] F. I. Khan and A. K. Ghoshal, "Review: removal of volatile organic compounds from polluted air," Journal of Loss Prevention in the Process Industries, vol. 13, pp. 527-545, 2000.

[16] R. Iranpour, H. H. J. Cox, M. A. Deshusses, and E. D. Schroeder, "Literature review of air pollution control biofilters and biotrickling filters for odor and volatile organic compound removal," Environmental Progress, vol. 24, no. 3, pp. 254-267, 2005.

[17] M. Tokumura, R. Nakajima, H. T. Znad, and Y. Kawase, "Chemical absorption process for degradation of VOC gas using heterogeneous gas-liquid photocatalytic oxidation: toluene degradation by photo-Fenton reaction," Chemosphere, vol. 73, no. 5, pp. 768-775, 2008.

[18] F. N. Aguero, M. R. Morales, F. G. Duran, B. P. Barbero, and L. E. Cadús, "MnCu/cordierite monolith used for catalytic combustion of volatile organic compounds," Chemical Engineering \& Technology, vol. 36, no. 10, pp. 1749-1754, 2013.

[19] K. Everaert and J. Baeyens, "Catalytic combustion of volatile organic compounds," Journal of Hazardous Materials, vol. 109, no. 1-3, pp. 113-139, 2004.

[20] S. Huang, C. Zhang, and H. He, "In situ adsorption-catalysis system for the removal of o-xylene over an activated carbon supported Pd catalyst," Journal of Environmental Sciences, vol. 21, no. 7, pp. 985-990, 2009.

[21] C. Q. Hu, "Catalytic combustion kinetics of acetone and toluene over $\mathrm{Cu}_{0.13} \mathrm{Ce}_{0.87} \mathrm{O}_{y}$ catalyst," Chemical Engineering Journal, vol. 168, no. 3, pp. 1185-1192, 2011.

[22] A. Urbutis and S. Kitrys, "Dual function adsorbent-catalyst $\mathrm{CuO}-\mathrm{CeO}_{2} / \mathrm{NaX}$ for temperature swing oxidation of benzene, toluene and xylene," Central European Journal of Chemistry, vol. 12, no. 4, pp. 492-501, 2014.

[23] W. B. Li, J. X. Wang, and H. Gong, "Catalytic combustion of VOCs on non-noble metal catalysts," Catalysis Today, vol. 148, no. 1-2, pp. 81-87, 2009. 
[24] A. Aranzabal, B. Pereda-Ayo, M. P. González-Marcos, J. A. González-Marcos, R. López-Fonseca, and J. R. GonzálezVelasco, "State of the art in catalytic oxidation of chlorinated volatile organic compounds," Chemical Papers, vol. 68, no. 9, pp. 1169-1186, 2014.

[25] J. C.-S. Wu and T.-Y. Chang, "VOC deep oxidation over Pt catalysts using hydrophobic supports," Catalysis Today, vol. 44, no. 1-4, pp. 111-118, 1998.

[26] S. Ordóñez, L. Bello, H. Sastre, R. Rosal, and F. V. Díez, "Kinetics of the deep oxidation of benzene, toluene, $n$-hexane and their binary mixtures over a platinum on $\gamma$-alumina catalyst," Applied Catalysis B: Environmental, vol. 38, no. 2, pp. 139-149, 2002.

[27] R. Beauchet, P. Magnoux, and J. Mijoin, "Catalytic oxidation of volatile organic compounds (VOCs) mixture (isopropanol/oxylene) on zeolite catalysts," Catalysis Today, vol. 124, no. 3-4, pp. 118-123, 2007.

[28] D. Ranković, Z. Arsenijević, N. Radić, B. Grbić, and Ž. Grbavčić, "Removal of volatile organic compounds from activated carbon by thermal desorption and catalytic combustion," Russian Journal of Physical Chemistry A, vol. 81, no. 9, pp. 1388-1391, 2007.

[29] A. E. Aksoylu, M. Madalena, A. Freitas, M. F. R. Pereira, and J. L. Figueiredo, "The effects of different activated carbon supports and support modifications on the properties of Pt/AC catalysts," Carbon, vol. 39, no. 2, pp. 175-185, 2001.

[30] H.-J. Joung, J.-H. Kim, J.-S. Oh, D.-W. You, H.-O. Park, and K.-W. Jung, "Catalytic oxidation of VOCs over CNT-supported platinum nanoparticles," Applied Surface Science, vol. 290, pp. 267-273, 2014.

[31] M. Guisnet, P. Dégé, and P. Magnoux, "Catalytic oxidation of volatile organic compounds 1 . Oxidation of xylene over a $0.2 \mathrm{wt} \% \mathrm{Pd} / \mathrm{HFAU}(17)$ catalyst," Applied Catalysis B: Environmental, vol. 20, no. 1, pp. 1-13, 1999.

[32] P. Dégé, L. Pinard, P. Magnoux, and M. Guisnet, "Catalytic oxidation of volatile organic compounds. II. Influence of the physicochemical characteristics of Pd/HFAU catalysts on the oxidation of o-xylene," Applied Catalysis B: Environmental, vol. 27, no. 1, pp. 17-26, 2000.

[33] S. Wahid and B. J. Tatarchuk, "Catalytic material with enhanced contacting efficiency for volatile organic compound removal at ultrashort contact time," Industrial \& Engineering Chemistry Research, vol. 52, no. 44, pp. 15494-15503, 2013.

[34] T. Barakat, V. Idakiev, R. Cousin et al., "Total oxidation of toluene over noble metal based $\mathrm{Ce}, \mathrm{Fe}$ and $\mathrm{Ni}$ doped titanium oxides," Applied Catalysis B: Environmental, vol. 146, pp. 138146, 2014.

[35] Z.-S. Liu, J.-Y. Chen, and Y.-H. Peng, "Activated carbon fibers impregnated with Pd and Pt catalysts for toluene removal," Journal of Hazardous Materials, vol. 256-257, pp. 49-55, 2013.

[36] K. Bendahou, L. Cherif, S. Siffert, H. L. Tidahy, H. Benaïssa, and A. Aboukaïs, "The effect of the use of lanthanum-doped mesoporous SBA-15 on the performance of Pt/SBA-15 and Pd/SBA-15 catalysts for total oxidation of toluene," Applied Catalysis A: General, vol. 351, no. 1, pp. 82-87, 2008.

[37] M.-W. Ryoo, S.-G. Chung, J.-H. Kim, Y. S. Song, and G. Seo, "The effect of mass transfer on the catalytic combustion of benzene and methane over palladium catalysts supported on porous materials," Catalysis Today, vol. 83, no. 1-4, pp. 131-139, 2003.

[38] J. J. S. Berland and B. Pavageau, "Palladium versus gold on modified ceria in VOCs combustion at low temperatures," in
Proceedings of the 11th European Congress on Catalysis, Lyon, France, September 2013.

[39] J. R. González-Velasco, A. Aranzabal, J. I. Gutiérrez-Ortiz, R. López-Fonseca, and M. A. Gutiérrez-Ortiz, "Activity and product distribution of alumina supported platinum and palladium catalysts in the gas-phase oxidative decomposition of chlorinated hydrocarbons," Applied Catalysis B: Environmental, vol. 19, no. 3-4, pp. 189-197, 1998.

[40] S. Minicò, S. Sciré, C. Crisafulli, R. Maggiore, and S. Galvagno, "Catalytic combustion of volatile organic compounds on gold/iron oxide catalysts," Applied Catalysis B: Environmental, vol. 28, no. 3-4, pp. 245-251, 2000.

[41] M. A. Centeno, M. Paulis, M. Montes, and J. A. Odriozola, "Catalytic combustion of volatile organic compounds on $\mathrm{Au} / \mathrm{CeO}_{2} / \mathrm{Al}_{2} \mathrm{O}_{3}$ and $\mathrm{Au} / \mathrm{Al}_{2} \mathrm{O}_{3}$ catalysts," Applied Catalysis A: General, vol. 234, no. 1-2, pp. 65-78, 2002.

[42] S. M. S. Scirè, S. Minicò, C. Crisafulli, C. Satriano, and A. Pistone, "Catalytic combustion of volatile organic compounds on gold/cerium oxide catalysts," Applied Catalysis B: Environmental, vol. 40, no. 1, pp. 43-49, 2003.

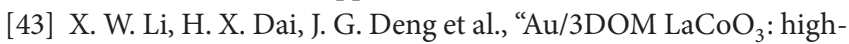
performance catalysts for the oxidation of carbon monoxide and toluene," Chemical Engineering Journal, vol. 228, pp. 965975, 2013.

[44] S. Minicò, S. Scirè, C. Crisafulli, A. M. Visco, and S. Galvagno, "FT-IR study of $\mathrm{Au} / \mathrm{Fe}_{2} \mathrm{O}_{3}$ catalysts for $\mathrm{CO}$ oxidation at low temperature," Catalysis Letters, vol. 47, no. 1-2, pp. 273-276, 1997.

[45] M. Haruta, N. Yamada, T. Kobayashi, and S. Iijima, "Gold catalysts prepared by coprecipitation for low-temperature oxidation of hydrogen and of carbon monoxide," Journal of Catalysis, vol. 115, no. 2, pp. 301-309, 1989.

[46] A. C. Gluhoi, N. Bogdanchikova, and B. E. Nieuwenhuys, "The effect of different types of additives on the catalytic activity of $\mathrm{Au} / \mathrm{Al}_{2} \mathrm{O}_{3}$ in propene total oxidation: transition metal oxides and ceria," Journal of Catalysis, vol. 229, no. 1, pp. 154-162, 2005.

[47] M. A. Centeno, M. Paulis, M. Montes, and J. A. Odriozola, "Catalytic combustion of volatile organic compounds on gold/titanium oxynitride catalysts," Applied Catalysis B: Environmental, vol. 61, no. 3-4, pp. 177-183, 2005.

[48] X. Zhang and A. Corma, "Supported gold(III) catalysts for highly efficient three-component coupling reactions," Angewandte Chemie-International Edition, vol. 47, no. 23, pp. 43584361, 2008.

[49] D. Ballestero, R. Juan, A. Ibarra et al., "Effect of thermal treatments on the morphology, chemical state and lattice structure of gold nanoparticles deposited onto carbon structured monoliths," Colloids and Surfaces A: Physicochemical and Engineering Aspects, vol. 468, pp. 140-150, 2015.

[50] J. Magura, A. Zeleňáková, V. Zeleňák, and M. Kaňuchová, "Thiol-modified gold nanoparticles deposited on silica support using dip coating," Applied Surface Science, vol. 315, no. 1, pp. 392-399, 2014.

[51] M. Paulis, H. Peyrard, and M. Montes, "Influence of chlorine on the activity and stability of $\mathrm{Pt} / \mathrm{Al}_{2} \mathrm{O}_{3}$ catalysts in the complete oxidation of toluene," Journal of Catalysis, vol. 199, no. 1, pp. 30 40, 2001.

[52] P. Broqvist, L. M. Molina, H. Grönbeck, and B. Hammer, "Promoting and poisoning effects of $\mathrm{Na}$ and $\mathrm{Cl}$ coadsorption on $\mathrm{CO}$ oxidation over MgO-supported Au nanoparticles," Journal of Catalysis, vol. 227, no. 1, pp. 217-226, 2004.

[53] S.-W. Baek, J.-R. Kim, and S.-K. Ihm, "Design of dual functional adsorbent/catalyst system for the control of VOC's by using 
metal-loaded hydrophobic Y-zeolites," Catalysis Today, vol. 9395, pp. 575-581, 2004.

[54] Q. Ye, J. Zhao, F. Huo et al., "Nanosized $\mathrm{Ag} / \alpha-\mathrm{MnO}_{2}$ catalysts highly active for the low-temperature oxidation of carbon monoxide and benzene," Catalysis Today, vol. 175, no. 1, pp. 603609, 2011.

[55] S. C. Kim and J. Y. Ryu, "Properties and performance of silver-based catalysts on the catalytic oxidation of toluene," Environmental Technology, vol. 32, no. 5, pp. 561-568, 2011.

[56] J. C. Zhou, D. F. Wu, W. D. Jiang, and Y. D. Li, "Catalytic combustion of toluene over a copper-manganese-silver mixedoxide catalyst supported on a washcoated ceramic monolith," Chemical Engineering \& Technology, vol. 32, no. 10, pp. 15201526, 2009.

[57] M. R. Morales, B. P. Barbero, and L. E. Cadús, "Total oxidation of ethanol and propane over Mn-Cu mixed oxide catalysts," Applied Catalysis B: Environmental, vol. 67, no. 3-4, pp. 229-236, 2006.

[58] V. H. Vu, J. Belkouch, A. Ould-Dris, and B. Taouk, "Catalytic oxidation of volatile organic compounds on manganese and copper oxides supported on titania," AIChE Journal, vol. 54, no. 6, pp. 1585-1591, 2008.

[59] N. Li and F. Gaillard, "Catalytic combustion of toluene over electrochemically promoted Ag catalyst," Applied Catalysis B: Environmental, vol. 88, no. 1-2, pp. 152-159, 2009.

[60] W. B. Li, W. B. Chu, M. Zhuang, and J. Hua, "Catalytic oxidation of toluene on Mn-containing mixed oxides prepared in reverse microemulsions," Catalysis Today, vol. 93-95, pp. 205-209, 2004.

[61] C.-H. Wang, " $\mathrm{Al}_{2} \mathrm{O}_{3}$-supported transition-metal oxide catalysts for catalytic incineration of toluene," Chemosphere, vol. 55, no. 1, pp. 11-17, 2004.

[62] M. F. Ribeiro, J. M. Silva, S. Brimaud et al., "Improvement of toluene catalytic combustion by addition of cesium in copper exchanged zeolites," Applied Catalysis B: Environmental, vol. 70, no. 1-4, pp. 384-392, 2007.

[63] M. Alifanti, M. Florea, and V. I. Pârvulescu, "Ceria-based oxides as supports for $\mathrm{LaCoO}_{3}$ perovskite; catalysts for total oxidation of VOC," Applied Catalysis B: Environmental, vol. 70, no. 1-4, pp. 400-405, 2007.

[64] B. P. Barbero, L. Costa-Almeida, O. Sanz, M. R. Morales, L. E. Cadus, and M. Montes, "Washcoating of metallic monoliths with a $\mathrm{MnCu}$ catalyst for catalytic combustion of volatile organic compounds," Chemical Engineering Journal, vol. 139, no. 2, pp. 430-435, 2008.

[65] D. Delimaris and T. Ioannides, "VOC oxidation over $\mathrm{MnO}_{x^{-}}$ $\mathrm{CeO}_{2}$ catalysts prepared by a combustion method," Applied Catalysis B: Environmental, vol. 84, no. 1-2, pp. 303-312, 2008.

[66] Y. X. X. Tang and W. Shen, "Promoting effect of copper on the catalytic activity of $\mathrm{MnO}_{x}-\mathrm{CeO}_{2}$ mixed oxide for complete oxidation of benzene," Chemical Engineering Journal, vol. 144, no. 2, pp. 175-180, 2008.

[67] W. B. Li, M. Zhuang, and J. X. Wang, "Catalytic combustion of toluene on $\mathrm{Cu}-\mathrm{Mn} / \mathrm{MCM}-41$ catalysts: influence of calcination temperature and operating conditions on the catalytic activity," Catalysis Today, vol. 137, no. 2-4, pp. 340-344, 2008.

[68] F. N. Aguero, B. P. Barbero, L. Gambaro, and L. E. Cadús, "Catalytic combustion of volatile organic compounds in binary mixtures over $\mathrm{MnOx} / \mathrm{Al}_{2} \mathrm{O}_{3}$ catalyst," Applied Catalysis B: Environmental, vol. 91, no. 1-2, pp. 108-112, 2009.

[69] S. C. Kim and W. G. Shim, "Catalytic combustion of VOCs over a series of manganese oxide catalysts," Applied Catalysis B: Environmental, vol. 98, no. 3-4, pp. 180-185, 2010.
[70] R. Beauchet, J. Mijoin, I. Batonneau-Gener, and P. Magnoux, "Catalytic oxidation of VOCs on NaX zeolite: mixture effect with isopropanol and o-xylene," Applied Catalysis B: Environmental, vol. 100, no. 1-2, pp. 91-96, 2010.

[71] S. M. Saqer, D. I. Kondarides, and X. E. Verykios, "Catalytic oxidation of toluene over binary mixtures of copper, manganese and cerium oxides supported on $\gamma-\mathrm{Al}_{2} \mathrm{O}_{3}$," Applied Catalysis $\mathrm{B}$ : Environmental, vol. 103, no. 3-4, pp. 275-286, 2011.

[72] G. Zhou, X. He, S. Liu, H. Xie, and M. Fu, "Phenyl VOCs catalytic combustion on supported CoMn/AC oxide catalyst," Journal of Industrial and Engineering Chemistry, vol. 21, pp. 932941, 2015.

[73] S. Krishnamoorthy, J. P. Baker, and M. D. Amiridis, "Catalytic oxidation of 1,2-dichlorobenzene over $\mathrm{V}_{2} \mathrm{O}_{5} / \mathrm{TiO}_{2}$-based catalysts," Catalysis Today, vol. 40, no. 1, pp. 39-46, 1998.

[74] S. Krishnamoorthy and M. D. Amiridis, "Kinetic and in situ FTIR studies of the catalytic oxidation of 1,2-dichlorobenzene over $\mathrm{V}_{2} \mathrm{O}_{5} / \mathrm{Al}_{2} \mathrm{O}_{3}$ catalysts," Catalysis Today, vol. 51, no. 2, pp. 203-214, 1999.

[75] S. Krishnamoorthy, J. A. Rivas, and M. D. Amiridis, "Catalytic oxidation of 1,2-dichlorobenzene over supported transition metal oxides," Journal of Catalysis, vol. 193, no. 2, pp. 264-272, 2000.

[76] F. Bertinchamps, C. Grégoire, and E. M. Gaigneaux, "Systematic investigation of supported transition metal oxide based formulations for the catalytic oxidative elimination of (chloro)aromatics-part I: identification of the optimal main active phases and supports," Applied Catalysis B: Environmental, vol. 66, no. 1-2, pp. 1-9, 2006.

[77] Y. Liu, M. Luo, Z. Wei, Q. Xin, P. Ying, and C. Li, “Catalytic oxidation of chlorobenzene on supported manganese oxide catalysts," Applied Catalysis B: Environmental, vol. 29, no. 1, pp. 61-67, 2001.

[78] Y. Liu, Z. Wei, Z. Feng, M. Luo, P. Ying, and C. Li, “Oxidative destruction of chlorobenzene and o-dichlorobenzene on a highly active catalyst: $\mathrm{MnOx} / \mathrm{TiO}_{2}-\mathrm{Al}_{2} \mathrm{O}_{3}$," Journal of Catalysis, vol. 202, no. 1, pp. 200-204, 2001.

[79] S. K. Samantaray and K. Parida, "Modified $\mathrm{TiO}_{2}-\mathrm{SiO}_{2}$ mixed oxides 1. Effect of manganese concentration and activation temperature towards catalytic combustion of volatile organic compounds," Applied Catalysis B: Environmental, vol. 57, no. 2, pp. 83-91, 2005.

[80] H. C. Genuino, S. Dharmarathna, E. C. Njagi, M. C. Mei, and S. L. Suib, "Gas-phase total oxidation of benzene, toluene, ethylbenzene, and xylenes using shape-selective manganese oxide and copper manganese oxide catalysts," Journal of Physical Chemistry C, vol. 116, no. 22, pp. 12066-12078, 2012.

[81] G. S. Pozan, "Effect of support on the catalytic activity of manganese oxide catalyts for toluene combustion," Journal of Hazardous Materials, vol. 221-222, pp. 124-130, 2012.

[82] M. R. Morales, B. P. Barbero, and L. E. Cadús, "Evaluation and characterization of $\mathrm{Mn}-\mathrm{Cu}$ mixed oxide catalysts for ethanol total oxidation: influence of copper content," Fuel, vol. 87, no. 7, pp. 1177-1186, 2008.

[83] S. Scirè, S. Minicò, C. Crisafulli, and S. Galvagno, "Catalytic combustion of volatile organic compounds over group IB metal catalysts on $\mathrm{Fe}_{2} \mathrm{O}_{3}$," Catalysis Communications, vol. 2, no. 6-7, pp. 229-232, 2001.

[84] J. I. Gutiérrez-Ortiz, B. de Rivas, R. López-Fonseca, S. Martín, and J. R. González-Velasco, "Structure of Mn-Zr mixed oxides catalysts and their catalytic performance in the gas-phase 
oxidation of chlorocarbons," Chemosphere, vol. 68, no. 6, pp. 1004-1012, 2007.

[85] G. Zhou, B. Gui, H. Xie et al., "Influence of $\mathrm{CeO}_{2}$ morphology on the catalytic oxidation of ethanol in air," Journal of Industrial and Engineering Chemistry, vol. 20, no. 1, pp. 160-165, 2014.

[86] S. Azalim, M. Franco, R. Brahmi, J.-M. Giraudon, and J.-F. Lamonier, "Removal of oxygenated volatile organic compounds by catalytic oxidation over $\mathrm{Zr}-\mathrm{Ce}-\mathrm{Mn}$ catalysts," Journal of Hazardous Materials, vol. 188, no. 1-3, pp. 422-427, 2011.

[87] S. Irusta, M. P. Pina, M. Menéndez, and J. Santamaría, "Catalytic combustion of volatile organic compounds over La-based perovskites," Journal of Catalysis, vol. 179, no. 2, pp. 400-412, 1998.

[88] R. Spinicci, M. Faticanti, P. Marini, S. De Rossi, and P. Porta, "Catalytic activity of $\mathrm{LaMnO}_{3}$ and $\mathrm{LaCoO}_{3}$ perovskites towards VOCs combustion," Journal of Molecular Catalysis A: Chemical, vol. 197, no. 1-2, pp. 147-155, 2003.

[89] D. S. S. A. Hosseini, A. Niaei, and S. A. Oskoui, "Physicalchemical property and activity evaluation of $\mathrm{LaB}_{0.5} \mathrm{Co}_{0.5} \mathrm{O}_{3}$ $(\mathrm{B}=\mathrm{Cr}, \mathrm{Mn}, \mathrm{Cu})$ and $\mathrm{LaMnxCo}_{1-x} \mathrm{O}_{3}(\mathrm{x}=0.1,0.25,0.5)$ nano perovskites in VOC combustion," Journal of Industrial and Engineering Chemistry, vol. 19, no. 6, pp. 1903-1909, 2013.

[90] G. Sinquin, C. Petit, J. P. Hindermann, and A. Kiennemann, "Study of the formation of LaMO3 ( $\mathrm{M}=\mathrm{Co}, \mathrm{Mn})$ perovskites by propionates precursors: application to the catalytic destruction of chlorinated VOCs," Catalysis Today, vol. 70, no. 1-3, pp. 183196, 2001.

[91] H. F. Huang, Z. Sun, H. F. Lu, L. Q. Shen, and Y. F. Chen, "Study on the poisoning tolerance and stability of perovskite catalysts for catalytic combustion of volatile organic compounds," Reaction Kinetics, Mechanisms and Catalysis, vol. 101, no. 2, pp. 417427, 2010.

[92] U. Zavyalova, B. Nigrovski, K. Pollok et al., "Gel-combustion synthesis of nanocrystalline spinel catalysts for VOCs elimination," Applied Catalysis B: Environmental, vol. 83, no. 3-4, pp. 221-228, 2008.

[93] M. H. Castaño, R. Molina, and S. Moreno, "Catalytic oxidation of VOCs on MnMgAlOx mixed oxides obtained by autocombustion," Journal of Molecular Catalysis A: Chemical, vol. 398, pp. 358-367, 2015.

[94] Y. Hammiche-Bellal, A. Benadda, L. Meddour-Boukhobza, S. Barama, A. Djadoun, and A. Barama, "Preparation and catalytic activity in ethanol combustion reaction of cobalt-iron spinel catalysts," Catalysis Communications, vol. 42, pp. 62-67, 2013.

[95] J. Okal and M. Zawadzki, "Catalytic combustion of methane over ruthenium supported on zinc aluminate spinel," Applied Catalysis A: General, vol. 453, pp. 349-357, 2013.

[96] S. Behar, N. Gómez-Mendoza, M. Gómez-García, D. Świerczyński, F. Quignard, and N. Tanchoux, "Study and modelling of kinetics of the oxidation of VOC catalyzed by nanosized $\mathrm{Cu}-\mathrm{Mn}$ spinels prepared via an alginate route," Applied Catalysis A: General, vol. 504, pp. 203-210, 2015.

[97] M. Brazlauskas and S. Kitrys, "Synthesis and properties of $\mathrm{CuO} /$ zeolite sandwich type adsorbent-catalysts," Chinese Journal of Catalysis, vol. 29, no. 1, pp. 25-30, 2008.

[98] M. A. Kolade, A. Kogelbauer, and E. Alpay, "Adsorptive reactor technology for VOC abatement," Chemical Engineering Science, vol. 64, no. 6, pp. 1167-1177, 2009.

[99] U. Roland, M. Kraus, F. Holzer, U. Trommler, and F.-D. Kopinke, "Selective dielectric heating for efficient adsorptive-catalytic cleaning of contaminated gas streams," Applied Catalysis A: General, vol. 474, pp. 244-249, 2014. 

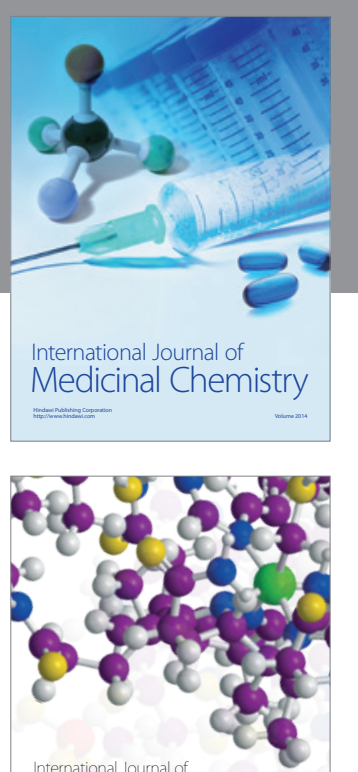

Carbohydrate Chemistry

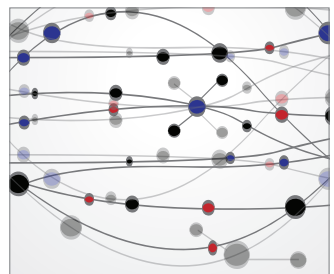

The Scientific World Journal
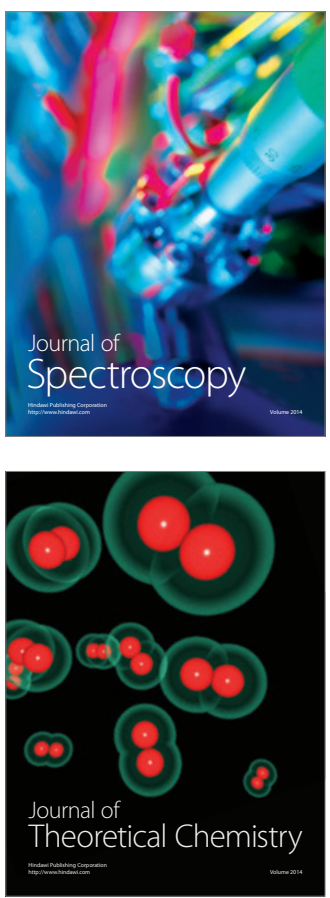
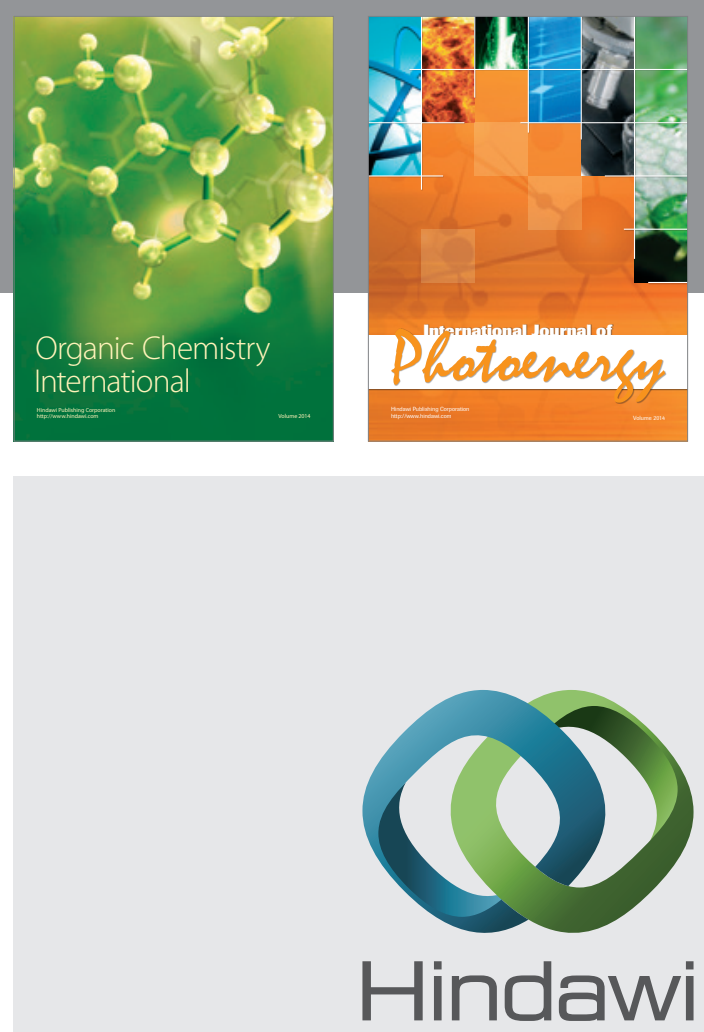

Submit your manuscripts at

http://www.hindawi.com

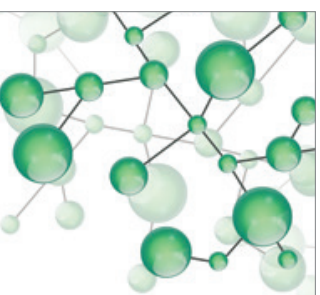

International Journal of

Inorganic Chemistry

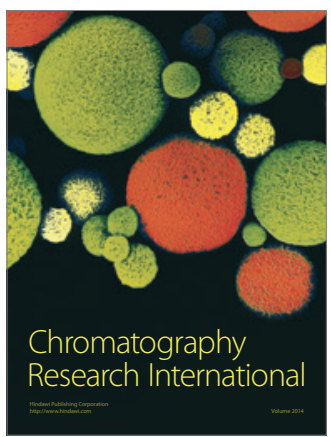

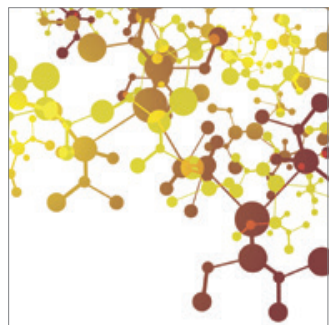

Applied Chemistry
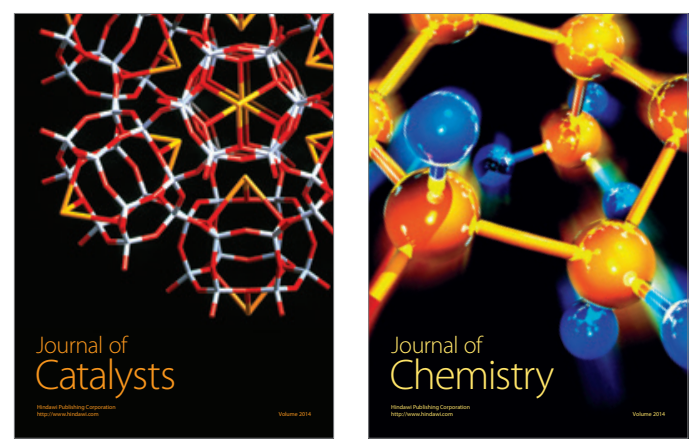
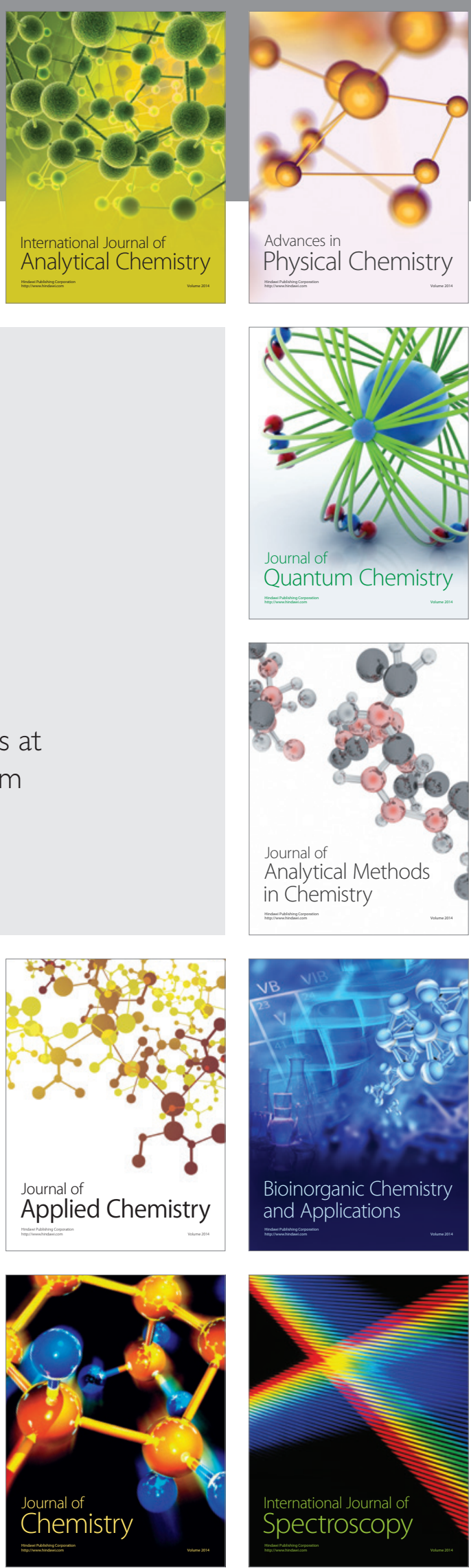